\title{
Evaluation of Bulk Cargo Dynamics in the ACTS Intermodal Container
}

\section{Procjena dinamike rasutih tereta u ACTS intermodalnom kontejneru}

\author{
Peter Marienka \\ University of Zilina \\ Faculty of Operation and Economics \\ of Transport and Communication \\ Department of Road and Urban \\ Transport, Slovakia \\ E-mail: peter.marienka@fpedas.uniza.sk
}

\author{
Marcel Frančák \\ University of Zilina \\ Faculty of Operation and Economics \\ of Transport and Communications \\ Department of Road and Urban \\ Transport, Slovakia \\ E-mail: marcel.francak@fpedas.uniza.sk
}

\author{
Juraj Jagelčák \\ University of Zilina \\ Faculty of Operation and Economics \\ of Transport and Communications \\ Department of Road and Urban \\ Transport, Slovakia \\ E-mail: juraj.jagelcak@fpedas.uniza.sk
}

\begin{abstract}
Summary
To ensure safety during transport within the intermodal chain, it is important to identify possible dynamic events that could affect the cargo. In the case of bulk cargo in an ACTS (Abroll-Container-Transport-System) container, the dynamics of the cargo and the vehicle vary during normal events such as braking, steering, evasive maneuver and the like. In this research, we used MEMS (Micro-Electro-Mechanical Systems) sensors to identify the parameters of acceleration at various points of container and to evaluate its impact on the cargo and vehicle. During the research, we also found out how the load of individual axles of the vehicle changed after performing normal dynamic events. One of the objectives was also to find out how parameters such as braking distance, braking time and mean fully developed deceleration (MFDD) change in the case of and empty and loaded ACTS container, as well as correlation analysis of values gathered from sensors placed on different parts of the container. The acquired knowledge can be used in the distribution and securing the cargo.
\end{abstract}

\section{Sažetak}

Kako bi se osigurala sigurnost tijekom transporta unutar intermodalnog lanca, važno je utvrditi moguće dinamičke događaje koji bi mogli utjecati na teret. $U$ slučaju rasutih tereta u kontejneru ACTS (Abroll-Container-Transport-System), različita je dinamika tereta i vozila tijekom normalnih događaja, kao što su: kočenje, upravljanje, manevar izbjegavanja i slično. $U$ ovom istraživanju koristili smo senzore MEMS (mikroelektromehanički sustavi) kako bismo identificirali parametre ubrzanja na različitim točkama kontejnera i procijenili njegov utjecaj na teret i vozilo. Tijekom istraživanja također smo otkrili kako se mijenjalo opterećenje pojedinih osovina vozila nakon izvođenja normalnih dinamičkih događaja. Jedan od ciljeva bio je otkriti kako se mijenjaju parametri, kao što su: put kočenja, vrijeme kočenja i prosječno puno usporenje (MFDD) u slučaju praznog i napunjenog ACTS kontejnera, kao i korelacijska analiza vrijednosti prikupljenih senzorima postavljenim na različitim dijelovima spremnika. Stečena znanja mogu se koristiti u raspodjeli i osiguranju tereta.

\author{
DOI 10.17818/NM/2021/1.2 \\ UDK 621.798 .13 \\ Original scientific paper / Izvorni znanstveni rad \\ Paper accepted / Rukopis primljen: 28. 5. 2020.
}

\section{INTRODUCTION / Uvod}

Safety is one of the key aspects of intermodal freight transport. The assessment of the correct distribution and securing of the cargo is based on the assumption of knowledge of the forces affecting the cargo, the intermodal load unit, and the vehicle. The cargo has different dynamics in normal or emergency situations, which can be measured and evaluated to identify the risk of damage to the cargo or vehicle. In the case of bulk cargo, this is more difficult to implement, as the cargo can only be secured in a very limited way. Transport of bulk cargo with high accelerations (decelerations) or large inclinations is quite different from the dynamics of common transport of cargo. To measure these dynamic events, it is necessary to use devices with accelerometers and gyroscopes. In order to determine the effect of these forces, a series of measurements must be taken with the ACTS container full of bulk cargo.

The importance of intermodal transport efficiency analysis is pointed out by Wiśnicki B. et al. [1]. Options of modeling of transport processes and transport mode choice are shown in the manuscript published by Gnap J. et al. [2],[3],[4]. The methodology of inland ports design as intermodal terminals in the Czech Republic was proposed in the article by Bínová and Jurkovič. [5]. Intermodal transport of goods can bring some specific shipments. One of them can be the transport of dangerous goods, which is described in Galierikova et al. article [6], as well as in Jagelcak J. et al. [7].

This article is also dedicated to axle load changes after dynamic events. There are many articles that deal with weight in intermodal transport, specifically article about VGM in intermodal transport by Jagelcak J. et al. [8] or about dynamic detection of the railway vehicles weight by Ližbetin J. et al. [10]. Nwokedi et al. assessed the shippers and ship owner's ships and charter type choice in the wet and dry bulk ship brokering market in the African region close to Nigeria [9]. 
Dynamic events described in this article were addressed in the past and many outputs are published, like simulation model of the dynamic behavior of refrigerated products in a ship's refrigerated container by Bupič M. et al. [12] or in applications of gyroscopic effect in transportation by Náhlík et al. [13]. The studies of vehicle dynamics lead to the safety of transport as described in Vlkovsky et al. articles [14], [27], [23] or in Skrucany et al. [17], [25], [28]. The aerodynamics, crosswind, safety systems, braking systems, cargo distribution must be taken into account as it is in articles by Gnap et al. [15],[21], Vrabel J. et al.[18], as well as Rybicka I. et al. [19] or Ondrus et al.[20] [24] [29]. These findings as well as information summarized in Rievaj V. et al. [22] [30] should be included in the research. The importance of using cameras to identify events in traffic is shown in Marienka P. et al. [16] and also in Tarkowski et al.[26]. As the article is also about the evaluation of dynamic events of transport for the purpose of cargo securing, it is necessary to take into account the research conducted in this area. Bańka et al. described lashing methods and mathematical basis of the process of selecting the number of lashings [11], while Stopka et al. determined the most suitable layout of space for the loading units' handling in the maritime port [40]. Kudlac et al. in their paper showed the identification of restricting criteria for a comprehensive assessment of logistics chains in intermodal transport [41]. Some of the findings used for the research were inspired by the article of Ližbetin and Stopka, in which authors proposed the case study of application of specific mathematical methods in the context of revitalization of defunct intermodal transport terminal [42].

\section{METHODS AND DEVICES / Metode i uređaji}

Measurements to determine the impact of the simulated transport events on the ACTS (Abroll-Container-Transport-System) intermodal container and the bulk cargo itself were performed within one day in a safe place so that the measurements do not endanger traffic safety or cause damage to the vehicle or cargo. Therefore, bulk cargo in the form of waste glass (bottles, sheet glass) was chosen, which was partially crushed. Dynamic events were measured using three sensors and two cameras on a MAN Abroller in combination with the ACTS container KAB-25, the parameters of which are given below.

\subsection{Vehicle - MAN Abroller / Vozilo MAN Abroller}

For handling the container and performing the measurements to evaluate the dynamics of the cargo in the ACTS container, a MAN Abroller vehicle was used. The vehicle is used to handle all ACTS containers up to a maximum length of 7 meters.

Table 1 Parameters of MAN TGS L.2007.46.004 Abroller Tablica 1. Parametri MAN TGS L.2007.46.004 Abroller

\begin{tabular}{l|l|} 
Vehicle & $\begin{array}{l}\text { N3G - Special lorry - BA hook lift } \\
\text { for container transport }\end{array}$ \\
\hline Configuration & $6 \times 4$ \\
\hline $\begin{array}{l}\text { Axles } \\
\text { Engine power }\end{array}$ & 3 axles \\
Gearbox & $309 \mathrm{~kW}$ \\
Empty weight & Manual 12 \\
\hline $\begin{array}{l}\text { Payload } \\
\text { Total weight }\end{array}$ & $12390 \mathrm{~kg}+$ ACTS container \\
\hline $\begin{array}{l}\text { Axle load } \\
\text { Axle wheelbases } \\
\text { Maximum length of the container }\end{array}$ & $7610 \mathrm{~kg}$ \\
\hline Source: Technical datasheet MAN & $26000 \mathrm{~kg}$ \\
\hline
\end{tabular}

2.2. ACTS container - KAB-25 / ACTS kontejner - KAB-25 Bulk cargo in the form of waste glass was loaded into an intermodal ACTS container with the model designation KAB-25, which is commonly used for the transport of waste. However, such a container may be intended for the carriage of any bulk cargo in any part of the intermodal chain. The container is manufactured in accordance with DIN 30722 standard.

Table 2 Parameters of ACTS container KAB-25

Tablica 2. Parametri ACTS kontejnera KAB-25

\begin{tabular}{ll}
\hline External dimensions & $6400 \times 2550 \times 1750 \mathrm{~mm}(\mathrm{LxWxH})$ \\
\hline Internal dimensions & $6000 \times 2480 \times 1500 \mathrm{~mm}(\mathrm{LxWxH})$ \\
\hline Gross mass & $17400 \mathrm{~kg}$ \\
Volume & $25 \mathrm{cbm}$ \\
\hline Tare (label) & $2400 \mathrm{~kg}$ \\
\hline Tare (weighed) & $2350 \mathrm{~kg}$ \\
\hline $\begin{array}{l}\text { Payload } \\
\text { Hook height }\end{array}$ & $15000 \mathrm{~kg}$ \\
Equipment & $1570 \mathrm{~mm}$ \\
\hline
\end{tabular}

Source: Technical datasheet of container KAB-25

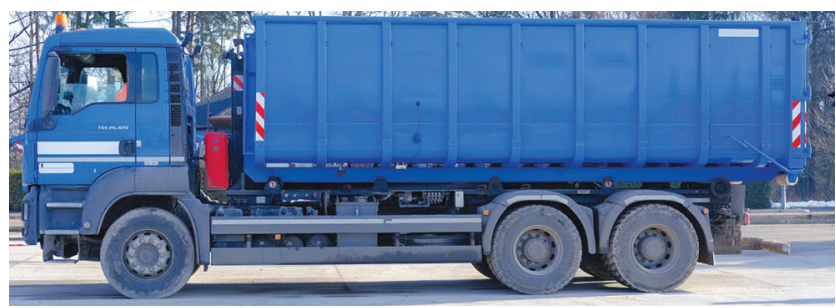

Figure 1 Vehicle with loaded container KAB-25

Slika 1. Vozilo s napunjenim kontejnerom KAB-25

Source: Authors

\subsection{Sensors S1 and S2 / Senzori S1 i S2}

MEMS (Micro-Electro-Mechanical Systems) sensors with a $\mathrm{BOSCH}$ accelerometer were used to measure the acceleration affecting the vehicles in various places of container. The accelerometer with a 14-bit LGA sensor can measure with different ranges. For the purposes of measurement the range was set to $\pm 8 \mathrm{~g}$ with a sensitivity of $1024 \mathrm{LSB} / \mathrm{g}$. In addition to the accelerometer, the MEMS also integrates a 3-axis gyroscope, i.e. an angular velocity sensor with a flexible measuring range. Identical sensors S1 and S2 can, in addition to acceleration and angular velocity, also record the UNIX time track and GPS position. The sampling frequency of the accelerometer is at the level of $200 \mathrm{~Hz}$.

\subsection{Sensor S3 / Senzor S3}

Sensors S1 and S2 were supplemented by a more accurate sensor S3, which was placed on the front of the loaded container. Sensor S3 is an acceleration sensor for evaluating the amount of acceleration (deceleration) of the service brake or the amount of acceleration. S3 is able to measure both positive and negative acceleration with a set range of $\pm 2 \mathrm{~g}$. Like S1 and S2, S3 can sample data at $200 \mathrm{~Hz}$, every $5 \mathrm{~ms}$. In addition to the measured data, the devices immediately evaluate the following indicators:

$\mathrm{v}_{0}$ - initial speed $\mathrm{v} \mathrm{km} / \mathrm{h}$;

$\mathrm{s}_{0}$ - braking distance in meters;

$\mathrm{T}_{\mathrm{br}}$ - total braking time in seconds;

MFDD - Mean Fully Developed Deceleration in $\mathrm{m} / \mathrm{s}^{2}$;

where the braking time $T_{b r}$ is calculated by the difference 
between the start braking time and the end braking time. The value of the initial vehicle speed $v_{0}$ is calculated by integrating the acceleration in the braking interval. The braking distance $\mathrm{s}_{0}$ is calculated as the double integral of the acceleration in the braking interval. The $\mathrm{S} 1$ sensor is a verified device for measuring the dynamics acting on a vehicle in the automotive industry.

\subsection{Cameras $\mathrm{C} 1$ and $\mathrm{C} 2$ / Kamere $\mathrm{C} 1$ i C2}

To monitor what is happening to the vehicle and the cargo at certain accelerations, it was necessary to supplement the used sensors with a video recording. For these purposes, two cameras were chosen, which were placed in the same places as the sensors S1 and S2. Cameras C1 and C2 are identical, they are 1080p HD @ 23.98 FPS cameras with CMOS sensor.

\section{DATA AND METHODOLOGY OF MEASUREMENTS / Podatci i metodologija mjerenja} Measurements with a loaded container were performed to identify the accelerations acting at different places of the ACTS container loaded with a bulk cargo in the form of waste glass. This load was chosen to eliminate the risk of damage to the cargo or the vehicle. For the purpose of these measurements, a MAN TGS 26.400 vehicle and ACTS container with the model designation KAB- 25 were used, which are described in Chapter 2 of this article.

Three sensors were used to measure dynamic events. The S1 was placed on the front half of the ACTS container and was firmly fixed to it by magnets. Sensor S2 was fixed to the container on the top rim of the container, while $\mathrm{S} 3$ was placed in the front half of the container. Cameras C1 and C2 were also placed at the same places as S1 and S2 so that the video captures not only the current situation of the left side of the vehicle but also the bulk cargo itself.

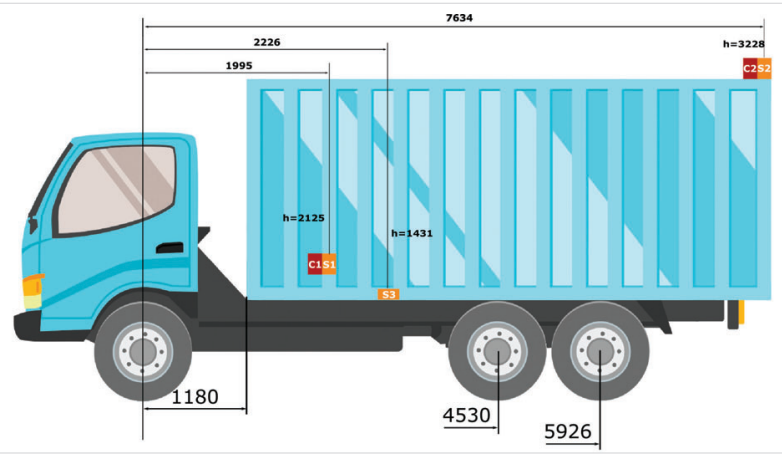

Figure 2 Scheme of the sensors and cameras locations during measurements

Slika 2. Shema položaja senzora i kamera tijekom mjerenja Source: Authors

The scheme in Figure 2 describes the location of the sensors and cameras on the vehicle during measurements and their position, i.e. the distance from the front axle of the vehicle and their height $(h)$. All dimensions are in millimeters.

To identify the dynamics acting on the vehicle, the container and the cargo, braking tests were chosen, while the driver was braking from an initial speed between 30 and $35 \mathrm{~km} / \mathrm{h}$. We made two series of these braking, while the total weight of the vehicle, as well as the weights of the front axle and the rear tandem axle were measured. During all measurements, selected indicators and accelerations given in multiples of $\mathrm{g}=9.81 \mathrm{~m} / \mathrm{s}^{2}$ were monitored.

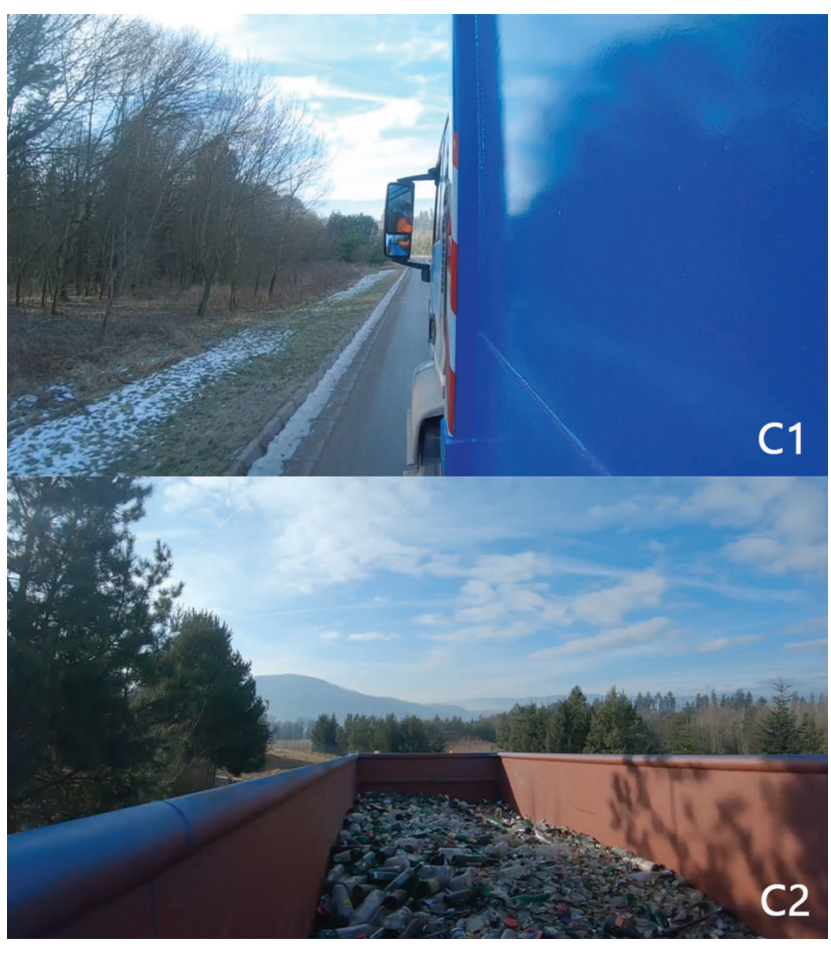

Figure 3 Views of $\mathrm{C} 1$ and $\mathrm{C} 2$.

Slika 3. Prikazi s $\mathrm{C} 1$ i C2

Source: Authors

\section{DATA EVALUATION / Procjena podataka}

From the cited monographs [30], [31], regulations [32], [33], [34], methodical instructions [35], [36] and standards [37], [38], it follows: the movement of a vehicle in traffic is uneven, depending on the circumstances it is necessary to accelerate, decelerate, change direction. From a safety point of view, one of the most important features is the efficiency of the brake system. In practice, the following requirements are imposed on the brakes:

- The braking system shall ensure a rapid and reliable stopping or deceleration of the vehicle or combination of vehicles at the speed, load condition, and gradient of the road which occurs during operation. The braking system must, therefore, be able to produce the required braking force on the circumference of all the wheels;

- The braking system of the individual wheels of the vehicle must be distributed among the individual wheels in such a way that braking does not impair the directional stability of the vehicle; The braking system must develop a braking effect even at an elevated temperature of the individual components of the braking system, which can be achieved e.g. during repeated intensive braking;

- The braking effect should be derived with the smallest possible time delay from the beginning of the action on the brake control.

When braking during real operation of the vehicle, as well as when evaluating the braking tests, it is necessary to realize that the course of braking deceleration is not constant, but changes over time. A simplified expression of the dependence of the magnitude of the braking deceleration in time can be seen in the graph in Fig. 4. 


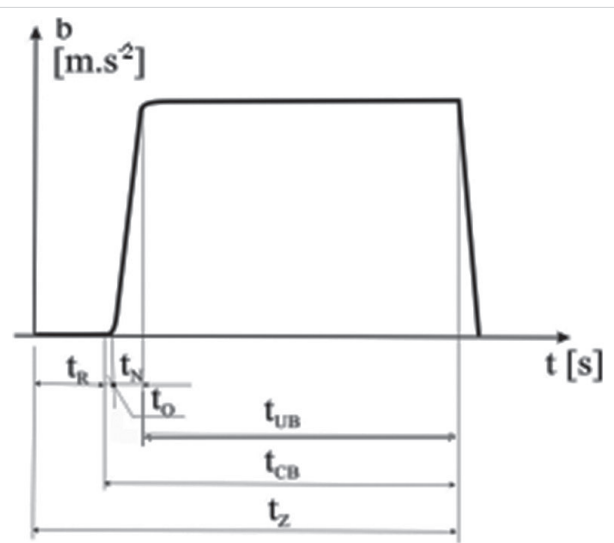

Figure 4 Theoretical course of braking Slika 4. Teorijski tijek kočenja

Source: Rievaj V., Sulgan M., Hudak A., Jagelcak J.: The car and its dynamics.

The $x$-axis shows the time and the $y$-axis shows the amount of braking deceleration. We assume that the vehicle travels at a constant speed before braking, so the magnitude of the braking deceleration is $0 \mathrm{~m} / \mathrm{s}^{2}$. At time $t_{0^{\prime}}$ the driver notices an obstacle or registers a braking stimulus. The $t_{r}$ reaction time follows. It is the time from the observation of an obstacle or stimulus to the moment when the driver decides to brake and touches the brake control mechanism. During this time, the vehicle is still moving at a constant speed, so the magnitude of the braking deceleration is still $0 \mathrm{~m} / \mathrm{s}^{2}$. This is followed by the delay time of the brakes, which lasts from the moment when the driver touches the brake control until the moment when the braking force begins to act. During this time, the mechanical clearance in the brake mechanism is defined. The delay time for the brakes is generally up to $0.15 \mathrm{~s}$ for air-assisted braking systems. When braking, we must also consider the time of onset of the braking effect. It is the time that elapses from the moment when the driver starts to act on the brake control element until the moment when the prescribed pressure is reached in the least favorably placed brake cylinder. According to UNECE Regulation 13 , the time that elapses from the time the driver begins to act on the brake control until the moment when the pressure that reached the last brake cylinder is equal to $75 \%$ of the nominal pressure and it must not be greater than $0.6 \mathrm{~s}$. During the rampup time, the braking deceleration increases from zero to full braking deceleration, i.e. the vehicle performs an unevenly decelerated movement. This is followed by the effective braking time here, during which the vehicle decelerated ideally evenly.

In practice, however, the vehicle decelerates unevenly due to the action of the ABS, as well as due to slight road irregularities, which is reflected in the value of braking deceleration during effective braking oscillating around a certain value - mean fully developed deceleration - MFDD.

The effectiveness of the braking system during the approval braking tests is also evaluated by MFDD. The MFDD can be determined from the stopping distance in relation to the initial speed of the vehicle by the formula:

$$
\mathrm{d}_{\mathrm{m}}=\frac{\mathrm{v}_{\mathrm{b}}^{2}-\mathrm{v}_{\mathrm{e}}^{2}}{25.92\left(\mathrm{~s}_{\mathrm{e}}-\mathrm{s}_{\mathrm{b}}\right)}\left[\mathrm{m} / \mathrm{s}^{2}\right]
$$

where:

$\mathrm{v}_{0}=$ initial vehicle speed in $\mathrm{km} / \mathrm{h}$

$\mathrm{v}_{\mathrm{b}}=$ vehicle speed at $0,8 \mathrm{v}_{\mathrm{o}}$ in $\mathrm{km} / \mathrm{h}$

$\mathrm{v}_{\mathrm{e}}=$ vehicle speed at $0,1 \mathrm{v}_{\mathrm{o}}$ in $\mathrm{km} / \mathrm{h}$

$\mathrm{s}_{\mathrm{b}}=$ distance traveled by the vehicle between $\mathrm{v}_{\mathrm{o}}$ and $\mathrm{v}_{\mathrm{b}}$ in metres

$\mathrm{s}_{\mathrm{e}}=$ distance traveled by the vehicle between $\mathrm{v}_{\mathrm{o}}$ and $\mathrm{v}_{\mathrm{e}}$ in metres.

The speed and distance shall be determined by instruments with and accuracy of $\pm 1 \%$ of the prescribed test speed. The MFDD can be determined in other ways than by measuring speed and distance. In this case, $d_{m}$ must be determined with and accuracy of $\pm 3 \%$.

The initial speed during the type-approval tests shall not be less than $98 \%$ of the speed for the prescribed test, which for vehicles of category N3 represents the value in the Type 0 test - basic cold brake test of $60 \mathrm{~km} / \mathrm{h}$ in the engine disconnected test and $80 \%$ of the maximum design vehicle speed but not exceeding $90 \mathrm{~km} / \mathrm{h}$ when tested with the engine connected. Also, during braking, the maximum permissible control force exerted by the driver on the brake control cannot be exceeded. For vehicles of category N3, this force shall not exceed 70 daN. The initial speed for Type 0 braking tests for selected vehicle categories are given in Table 3. We can also see the maximum braking distance and the minimum required MFDD for vehicle type-approval.

where:

$\mathrm{v}=$ prescribed test speed in $\mathrm{km} / \mathrm{h}$

$\mathrm{s}=$ braking distance in meters

$\mathrm{d}_{\mathrm{m}}=$ mean fully developed deceleration in $\mathrm{m} / \mathrm{s}^{2}$

$\mathrm{F}=$ control force in daN

$\mathrm{v}_{\max }=$ maximum vehicle speed in $\mathrm{km} / \mathrm{h}$.

Table 3 Initial speeds for Type 0 braking tests for selected vehicle categories Tablica 3. Početna brzina za ispitivanja kočenja Tipa 0 za odabrane kategorije vozila

\begin{tabular}{|c|c|c|c|c|c|c|}
\hline & Category & M2 & M3 & N1 & N2 & N3 \\
\hline \multirow{3}{*}{$\begin{array}{l}\text { Type } 0 \text { test with engine } \\
\text { disconnected }\end{array}$} & v & $60 \mathrm{~km} / \mathrm{h}$ & $60 \mathrm{~km} / \mathrm{h}$ & $80 \mathrm{~km} / \mathrm{h}$ & $60 \mathrm{~km} / \mathrm{h}$ & $60 \mathrm{~km} / \mathrm{h}$ \\
\hline & $\mathrm{s}$ & \multicolumn{5}{|c|}{$0.15 v+\frac{v^{2}}{130}$} \\
\hline & $\mathrm{d}_{\mathrm{m}}$ & \multicolumn{5}{|c|}{$5.0 \mathrm{~m} / \mathrm{s} 2$} \\
\hline \multirow{4}{*}{$\begin{array}{l}\text { Type } 0 \text { test with engine } \\
\text { connected }\end{array}$} & $v=0.80 v_{\max }$ but not exceeding & $100 \mathrm{~km} / \mathrm{h}$ & $90 \mathrm{~km} / \mathrm{h}$ & $120 \mathrm{~km} / \mathrm{h}$ & $100 \mathrm{~km} / \mathrm{h}$ & $90 \mathrm{~km} / \mathrm{h}$ \\
\hline & $\mathrm{s}$ & \multicolumn{5}{|c|}{$0.15 v+\frac{v^{2}}{103 .}$} \\
\hline & $\mathrm{d}_{\mathrm{m}}$ & \multicolumn{5}{|c|}{$4.0 \mathrm{~m} / \mathrm{s}^{2}$} \\
\hline & $\mathrm{F}$ & \multicolumn{5}{|c|}{70} \\
\hline
\end{tabular}

Source: Regulation No 13 of the Economic Commission for Europe of the United Nations (UN/ECE) — Uniform provisions concerning the approval of vehicles of categories M, N and O with regard to braking [2016/194]. 
In the Slovak Republic, it is obligatory to subject vehicles operated on-road to technical inspections at regular intervals depending on the category of vehicles, which are listed in $\S 47$ of the Decree of the Ministry of Transport and Construction of the Slovak Republic no. 137/2018 Coll., which lays down details on technical inspections. For vehicles of category N3 there is the obligation to pass the technical inspection within one year from its first registration and then periodically within one year.

During the technical inspection, the inspection of control items is divided into 10 groups, while for each group methodological instructions are issued indicating which components are to be checked and how. Brake systems belong to group 1. One of the control items of group 1 is to determine the magnitude of the braking effect. The braking effect can be measured by technical inspection stations in two ways - by driving test and by means of a roller brake tester. The braking performance test is generally performed on vehicles where it is not possible to perform the test on a cylinder brake test rig either in terms of their dimensions or in terms of their design. For the procedure for determining the effect of brakes on a roller brake tester, the Slovak Republic has issued Methodical instruction of the Ministry of Transport and Construction of the Slovak Republic no. 74/2018 for performing inspections of brake systems of vehicles of categories $\mathrm{M} 1$ with the maximum permissible weight over 3.5t, M2, M3, N2, N3, O3, and O4 on roller brake tester. For a vehicle of category N3 to be technically fit for braking performance, it is necessary to achieve the prescribed braking. The braking factor can be calculated according to the relation:

$$
\mathrm{Z}=10.2 * \sum \mathrm{B}_{\mathrm{vi}} / \mathrm{m}_{\mathrm{c}}
$$

where:

$\Sigma B_{v i}$ is the sum of the braking forces at the circumference of the axle wheels I given in $\mathrm{N}$,

$\mathrm{m}_{\mathrm{c}}$ is the maximum permissible gross vehicle mass stated in $\mathrm{kg}$ (the figure is given in F.1 of the registration certificate Part I and the registration certificate Part II).

According to the standard STN EN 12195-1:2010, in connection with the inertial forces considered for the design of load securing, the acceleration coefficients $c_{x^{\prime}} c_{y}$ and $c_{z}$ are used. An acceleration coefficient determined, for example, of $0.8 \mathrm{~g}$ in a given direction, means that it is necessary to secure $80 \%$ of the weight of the load in a given direction.

According to the standard prEN17321:2020, when dynamic acceleration tests are performed, minimum acceleration dwell time shall be $300 \mathrm{~ms}$. The test value is the minimum acceleration recorded during the dwell time. When dynamic driving tests are performed, minimum acceleration dwell time shall be $1000 \mathrm{~ms}$. While a duration of $80 \mathrm{~ms}$ the arithmetic average shall meet the required acceleration value. The arithmetic average of the required acceleration is allowed to fall below the required value by $0.05 \mathrm{~g}$ in case this value is applied over a period of one second.

Table 4 Prescribed braking values and their conversion to the actual deceleration achieved during braking Tablica 4. Propisane vrijednosti kočenja i njihovo pretvaranje u stvarno usporavanje postignuto tijekom kočenja

\begin{tabular}{|l|c|c|c|}
\hline & $\begin{array}{c}\text { Vehicles of cat. N3 in first } \\
\text { evidence from 1.1.2012 }\end{array}$ & $\begin{array}{c}\text { Vehicles of cat. N3 in first } \\
\text { evidence in 1988 to 1.1.2012 }\end{array}$ & $\begin{array}{c}\text { Vehicles of cat. N3 in first } \\
\text { evidence to 1988 }\end{array}$ \\
\hline braking factor [\%] & $50 \%$ & $45 \%$ & $43 \%$ \\
\hline deceleration [g] & 0.5 & 0.45 & 0.43 \\
\hline deceleration $\left[\mathrm{m} / \mathrm{s}^{2}\right]$ & 4.9 & 4.4 & 4.2 \\
\hline
\end{tabular}

Source: Methodical instruction of the Ministry of Transport and Construction of the Slovak Republic no. 48/2018, which lays down control items related to the braking device.

Table 5 Acceleration coefficients $c_{x^{\prime}} c_{y}$ and $c_{z}$ for road, rail, and sea transport

Tablica 5. Koeficijenti ubrzanja $c_{x^{\prime}} c_{y}$ i $c_{z}$ za cestovni, željeznički i pomorski promet

\begin{tabular}{|c|c|c|c|c|c|c|}
\hline \multicolumn{7}{|c|}{ Road transport } \\
\hline \multirow{3}{*}{ Securing in } & \multicolumn{6}{|c|}{ Acceleration coefficients } \\
\hline & \multicolumn{2}{|c|}{ Longitudinal $\left(c_{x}\right)$} & \multicolumn{2}{|c|}{ Transversely $\left(c_{y}\right)$} & \multirow{2}{*}{\multicolumn{2}{|c|}{ Vertically down $\left(c_{z}\right)$}} \\
\hline & forward & rear & Slide only & Turnover & & \\
\hline Longitudinal direction & 0.8 & 0.5 & - & - & & \\
\hline Transverse direction & - & - & 0.5 & $0.5 / 0.6$ & & \\
\hline \multicolumn{7}{|c|}{ Rail transport } \\
\hline \multirow{3}{*}{ Securing in } & \multicolumn{6}{|c|}{ Acceleration coefficients } \\
\hline & \multicolumn{2}{|c|}{ Longitudinal $\left(c_{x}\right)$} & \multirow{2}{*}{\multicolumn{2}{|c|}{ Transversely $\left(c_{y}\right)$}} & \multicolumn{2}{|c|}{ Minimum vertically down $\left(c_{z}\right)$} \\
\hline & forward & rear & & & Slide only & Turnover \\
\hline Longitudinal direction & 1.0 & 0.6 & & & 1.0 & 1.0 \\
\hline Transverse direction & - & - & & & 0.7 & 1.0 \\
\hline \multicolumn{7}{|c|}{ Sea transport } \\
\hline \multirow{2}{*}{ Sea area } & \multirow{2}{*}{ Securing in } & \multicolumn{5}{|c|}{ Acceleration coefficients } \\
\hline & & Longitudinal $\left(c_{x}\right)$ & & ersely $\left(c_{y}\right)$ & Minimum & cally down $\left(c_{z}\right)$ \\
\hline \multirow{2}{*}{ A } & Longitudinal direction & 0.3 & & - & & \\
\hline & Transverse direction & - & & 0.5 & & \\
\hline \multirow{2}{*}{ B } & Longitudinal direction & 0.3 & & - & & \\
\hline & Transverse direction & - & & 0.7 & & \\
\hline \multirow{2}{*}{$\mathrm{C}$} & Longitudinal direction & 0.4 & & - & & \\
\hline & Transverse direction & - & & 0.8 & & \\
\hline
\end{tabular}

Source: EN 12195-1:2010. Load restraining on road vehicles. Safety. Calculation of securing forces. 


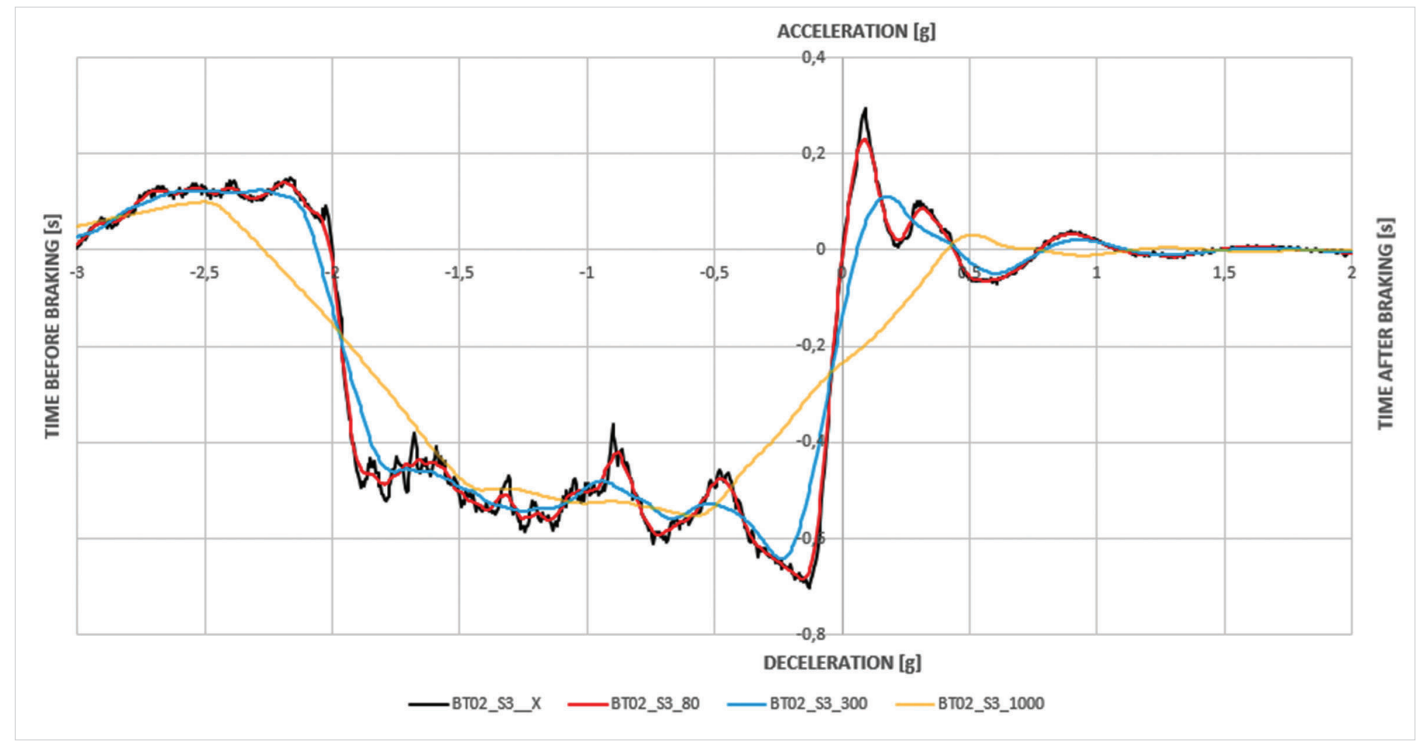

Figure 5 RAW data and application of moving averages $80 \mathrm{~ms}, 300 \mathrm{~ms}$ and $1000 \mathrm{~ms}$.

Slika 5. RAW podatci i primjena pokretnih prosjeka $80 \mathrm{~ms}, 300 \mathrm{~ms}$ i $1000 \mathrm{~ms}$

Source: Authors

For this reason, the raw data were filtered with a moving average of $80 \mathrm{~ms}, 300 \mathrm{~ms}$ and $1000 \mathrm{~ms}$. The influence of these filters can be seen in Fig. 5. The maximum deceleration for the individual sensors is then shown in the tables.

\subsection{Braking tests with empty container / Ispitivanja kočenja s praznim kontejnerom}

The performed measurements can be divided into two main parts. In the first part, 8 braking tests were performed with an empty container using three sensors, while the measured maximum deceleration values for individual sensors with the application of three filters are shown in Table 6. The breaking courses with filters application are shown in Fig. 6.

\subsection{Braking tests with loaded container / Ispitivanja kočenja s natovarenim kontejnerom}

After performing the braking tests with the empty container, the container was loaded with waste glass weighing $9010 \mathrm{~kg}$. With the loaded container, another 8 braking tests were performed. After four braking tests a short driving test was performed to monitor the movement of the bulk cargo in the container. The maximum values of decelerations for individual sensors with the application of three filters are shown in Table 7. The courses of measured braking decelerations using filters of $80 \mathrm{~ms}, 300$ $\mathrm{ms}$, and $1000 \mathrm{~ms}$ are shown in Figure 7.

Table 6 Braking tests with empty container (measurements BT01-08) Tablica 6. Ispitivanja kočenja s praznim kontejnerom (mjere BT01-08)

\begin{tabular}{|c|c|c|c|c|c|c|c|c|c|c|c|c|c|}
\hline \multirow{3}{*}{ ID } & \multirow{3}{*}{$\begin{array}{c}\mathrm{s}_{0} \\
{[\mathrm{~m}]}\end{array}$} & \multirow{3}{*}{$\begin{array}{c}v_{0} \\
{[\mathrm{~km} / \mathrm{h}]}\end{array}$} & \multirow{3}{*}{$\begin{array}{l}T_{b r} \\
{[s]}\end{array}$} & \multirow{3}{*}{$\begin{array}{l}\text { MFDD } \\
{\left[\mathrm{m} / \mathrm{s}^{2}\right]}\end{array}$} & \multicolumn{9}{|c|}{ Maximum deceleration [g] } \\
\hline & & & & & \multicolumn{3}{|c|}{ S1 } & \multicolumn{3}{|c|}{$\mathrm{S} 2$} & \multicolumn{3}{|c|}{ S3 } \\
\hline & & & & & $80 \mathrm{~ms}$ & $300 \mathrm{~ms}$ & $1000 \mathrm{~ms}$ & $80 \mathrm{~ms}$ & $300 \mathrm{~ms}$ & $1000 \mathrm{~ms}$ & $80 \mathrm{~ms}$ & $300 \mathrm{~ms}$ & $1000 \mathrm{~ms}$ \\
\hline BT01 & 10.43 & 35.65 & 2.02 & 5.16 & -0.7114 & -0.5787 & -0.5362 & -0.7353 & -0.5844 & -0.5414 & -0.6364 & -0.5749 & -0.5362 \\
\hline BT02 & 10.29 & 35.64 & 1.97 & 5.18 & -0.7033 & -0.6483 & -0.5443 & -0.7068 & -0.6549 & -0.5479 & -0.6849 & -0.6426 & -0.5535 \\
\hline BT03 & 9.50 & 34.15 & 1.87 & 5.60 & -0.6824 & -0.6077 & -0.5764 & -0.7012 & -0.6129 & -0.5774 & -0.6588 & -0.6051 & -0.5792 \\
\hline BT04 & 9.40 & 34.17 & 1.90 & 5.30 & -0.6478 & -0.6064 & -0.5539 & -0.6593 & -0.6134 & -0.5436 & -0.6417 & -0.6119 & -0.5514 \\
\hline BT05 & 9.12 & 32.40 & 1.90 & 5.09 & -0.6729 & -0.6292 & -0.5245 & -0.6817 & -0.6817 & -0.5358 & -0.6617 & -0.6274 & -0.5365 \\
\hline BT06 & 8.56 & 32.22 & 1.78 & 5.46 & -0.7330 & -0.6905 & -0.6031 & -0.7414 & -0.6527 & -0.5811 & -0.6814 & -0.6451 & -0.5776 \\
\hline BT07 & 9.33 & 33.45 & 1.87 & 5.41 & -0.7217 & -0.6041 & -0.5713 & -0.6969 & -0.6093 & -0.5754 & -0.6752 & -0.5922 & -0.5701 \\
\hline BT08 & 9.95 & 35.21 & 1.98 & 5.17 & -0.7189 & -0.6930 & -0.5813 & -0.7156 & -0.6863 & -0.5755 & -0.6971 & -0.6658 & -0.5666 \\
\hline
\end{tabular}

Source: Authors 


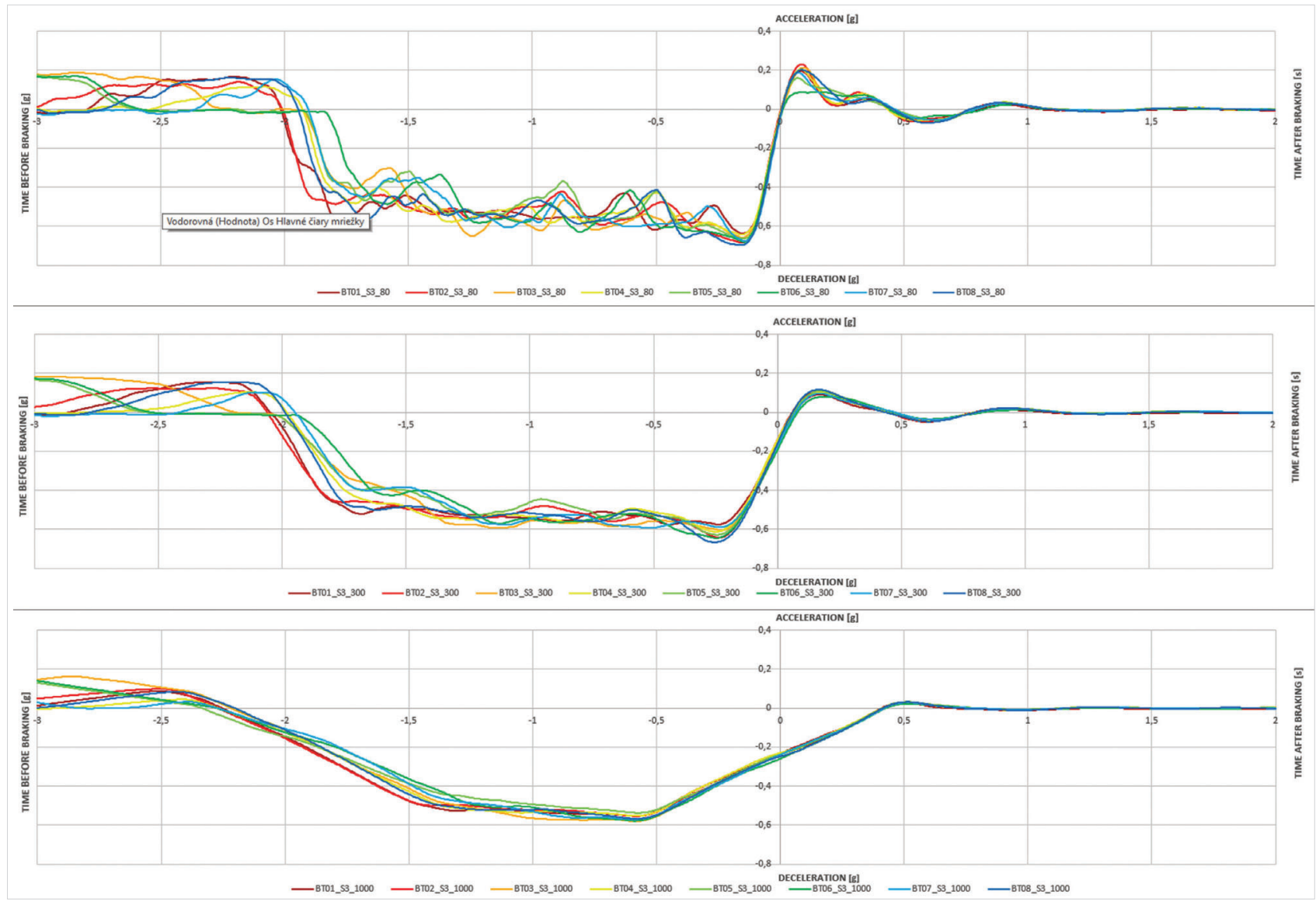

Figure 6 Braking tests BT01-08 measured with S3 and applied moving average filters

Source: Authors Slika 6. Ispitivanja kočenja BT01-08 izmjerena sa S3 i primijenjeni filtri s pomičnim prosjekom

Table 7 Braking tests with loaded container (measurements BT09-16)

Tablica 7. Ispitivanja kočenja s natovarenim kontejnerom (mjere BT09-16)

\begin{tabular}{|c|c|c|c|c|c|c|c|c|c|c|c|c|c|}
\hline \multirow{3}{*}{ ID } & \multirow{3}{*}{$\begin{array}{c}s_{0} \\
{[\mathrm{~m}]}\end{array}$} & \multirow{3}{*}{$\begin{array}{c}v_{0} \\
{[\mathrm{~km} / \mathrm{h}]}\end{array}$} & \multirow{3}{*}{$\begin{array}{l}\mathrm{T}_{\mathrm{br}} \\
{[\mathrm{s}]}\end{array}$} & \multirow{3}{*}{$\begin{array}{l}\text { MFDD } \\
{\left[\mathrm{m} / \mathrm{s}^{2}\right]}\end{array}$} & \multicolumn{9}{|c|}{ Maximum deceleration [g] } \\
\hline & & & & & \multicolumn{3}{|c|}{ S1 } & \multicolumn{3}{|c|}{ S2 } & \multicolumn{3}{|c|}{ S3 } \\
\hline & & & & & $80 \mathrm{~ms}$ & $300 \mathrm{~ms}$ & $1000 \mathrm{~ms}$ & oums & $300 \mathrm{~ms}$ & 000 & oums & $300 \mathrm{~ms}$ & $1000 \mathrm{~ms}$ \\
\hline BT09 & 8.33 & 32.14 & 1.75 & 5.44 & -0.6938 & -0.6551 & -0.5867 & -0.7631 & -0.6566 & -0.5 & -0.6789 & -0.6436 & -0.5857 \\
\hline BT10 & 9.06 & 32.72 & 1.92 & 5.18 & -0.6460 & -0.5757 & -0.5465 & -0.7414 & -0.6156 & -0.5398 & -0.5915 & -0.5614 & -0.5435 \\
\hline BT11 & 8.50 & 2.16 & 1.80 & 5.42 & -0.6571 & -0.5975 & -0.5733 & -0.6589 & -0.5967 & -0.5715 & -0.6452 & -0.5902 & -0.5711 \\
\hline BT12 & 8.87 & 31.99 & 1.90 & 5.05 & $N / A^{*}$ & $N / A^{*}$ & $N / A^{*}$ & $N / A^{*}$ & $N / A^{*}$ & $N / A^{*}$ & -0.5677 & -0.5129 & -0.4900 \\
\hline BT13 & 8.70 & (0) & 1.91 & 5.00 & $-0.61 / 2$ & -0.5452 & -0.5240 & -0.1618 & -0.J0د5 & -0.J30/ & -0.6042 & -0.5507 & -0.5248 \\
\hline BT14 & 9.21 & 32.34 & 1.93 & 5.13 & -0.6413 & -0.5919 & -0.5365 & -0.7742 & -0.6188 & -0.5393 & -0.6032 & -0.5663 & -0.5236 \\
\hline BT15 & 10.3 & 35.60 & 2.03 & 5.04 & -0 & -0 & & -0. & -0 . & -0 & -0.6351 & -0.5903 & -0.5369 \\
\hline BT16 & 7.10 & 9.11 & 1.72 & 5.17 & -0.6407 & -0.5884 & -0.5286 & -0.7368 & -0.6168 & -0.5292 & -0.6205 & -0.5940 & -0.5217 \\
\hline
\end{tabular}

Source: Authors

${ }^{*} \mathrm{~N} / \mathrm{A}$ - measurement error, data not available

N/A - grješka mjerenja, podatci nisu dostupni

\subsection{Comparison of braking distance, braking time and MFDD with empty and loaded container / Usporedba puta kočenja, vremena kočenja i MFDD-a s praznim $i$ napunjenim kontejnerom}

This section compares the mean fully developed deceleration (MFDD), braking distance, and braking time for both empty and loaded containers.
A comparison of braking distance, braking time and MFDD are shown in the graphs in Figure 8. In general, the braking distance reduced when the container was loaded and the MFDD was also reduced to some extent. According to Regulation No 13 of the Economic Commission for Europe of the United Nations (UN/ECE), the MFDD must be at least $5 \mathrm{~m} / \mathrm{s}^{2}$, which has been achieved in all cases. 


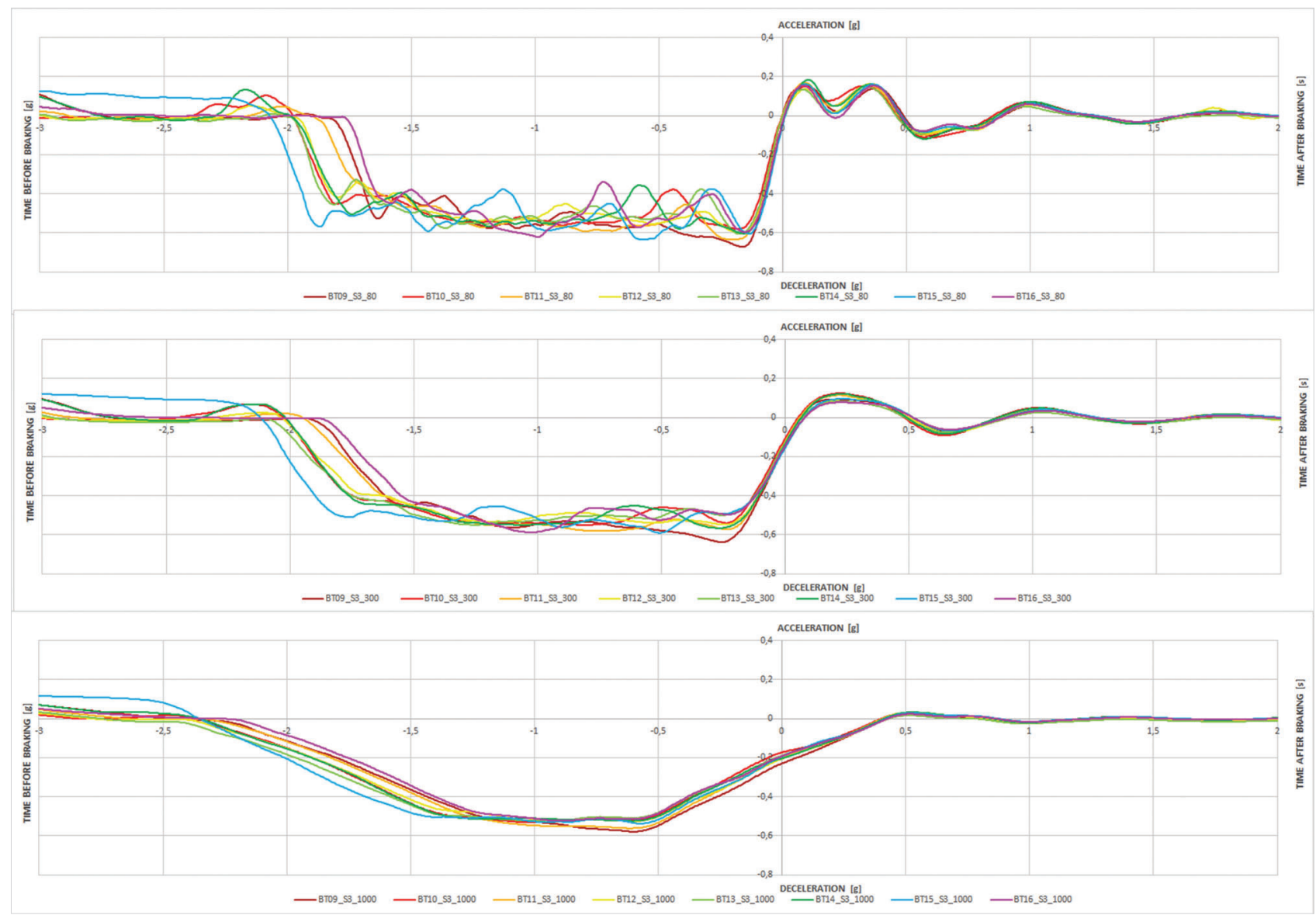

Figure 7 Braking tests BT01-08 measured with S3 and applied moving average filters Source: Authors Slika 7. Ispitivanja kočenja BT01-08 izmjerena sa S3 i primijenjeni filtri s pomičnim prosjekom

Table 8 Comparison of braking distance, braking time and MFDD Tablica 8. Usporedba puta kočenja, vremena kočenja i MFDD- $a$

\begin{tabular}{|c|c|c|c|c|c|c|c|c|c|c|c|c|c|c|c|}
\hline & ID & $\begin{array}{c}\mathrm{s}_{0} \\
{[\mathrm{~m}]}\end{array}$ & $\begin{array}{c}\mathrm{v}_{0} \\
{[\mathrm{~km} / \mathrm{h}]}\end{array}$ & $\begin{array}{l}\mathrm{T}_{\mathrm{br}} \\
{[\mathrm{s}]}\end{array}$ & $\begin{array}{l}\text { MFDD } \\
{\left[\mathrm{m} / \mathrm{s}^{2}\right]}\end{array}$ & & ID & $\begin{array}{c}\mathrm{s}_{0} \\
{[\mathrm{~m}]}\end{array}$ & $\begin{array}{l}\text { Diff } \\
{[\mathrm{m}]}\end{array}$ & $\begin{array}{c}\mathrm{v}_{0} \\
{[\mathrm{~km} / \mathrm{h}]}\end{array}$ & $\begin{array}{c}\text { Diff } \\
{[\mathrm{km} / \mathrm{h}]}\end{array}$ & $\begin{array}{l}\mathrm{T}_{\mathrm{br}} \\
{[\mathrm{s}]}\end{array}$ & Diff [s] & $\begin{array}{l}\text { MFDD } \\
{\left[\mathrm{m} / \mathrm{s}^{2}\right]}\end{array}$ & $\begin{array}{c}\text { Diff } \\
{\left[\mathrm{m} / \mathrm{s}^{2}\right]}\end{array}$ \\
\hline \multirow{8}{*}{ 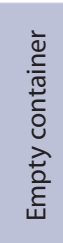 } & BT01 & 10.43 & 35.65 & 2.02 & 5.16 & \multirow{8}{*}{ 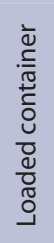 } & BT09 & 8.33 & -2.10 & 32.14 & -3.51 & 1.75 & -0.27 & 5.44 & +0.28 \\
\hline & BT02 & 10.29 & 35.64 & 1.97 & 5.18 & & BT10 & 9.06 & +1.23 & 32.72 & -2.92 & 1.92 & -0.05 & 5.18 & 0 \\
\hline & BT03 & 9.50 & 34.15 & 1.87 & 5.60 & & BT11 & 8.50 & -1.00 & 32.16 & -1.99 & 1.80 & -0.07 & 5.42 & -0.18 \\
\hline & BT04 & 9 & 34.17 & 1.90 & 5.30 & & BT12 & 8. & 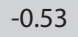 & 31.99 & -2 & 1.90 & 0 & 5. & -0.25 \\
\hline & BT05 & 9.12 & 32.40 & 1.90 & 5.09 & & BT13 & 8.70 & -0.42 & 31.85 & -0.5 & 1.91 & +0.01 & 5.00 & -0.09 \\
\hline & BT06 & 8.56 & 2 & 1.78 & 5.46 & & BT14 & 9.21 & +0.65 & 32.34 & +0.12 & 1.93 & +0.15 & 5.13 & -0.33 \\
\hline & BT07 & 9.33 & 33.45 & 1.87 & 5.41 & & BT15 & 10.30 & +0.97 & 35.60 & +2.15 & 2.03 & +0.16 & 5.04 & -0.37 \\
\hline & BT08 & 9.95 & 35.21 & 1.98 & 5.17 & & BT16 & 7.10 & -2.85 & 29.11 & -6.1 & 1.72 & -0.26 & 5.17 & v \\
\hline
\end{tabular}

Source: Authors

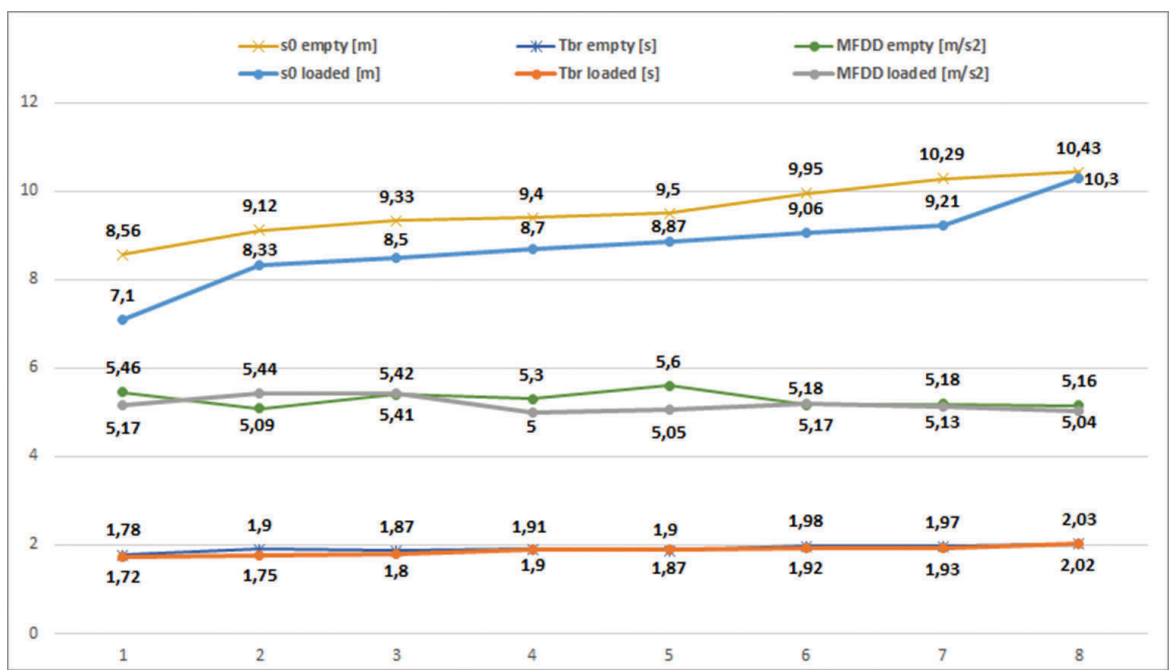

Figure 8 The differences of MFDD, braking distance and braking time with empty and loaded container Slika 8. Razlike MFDD-a, puta kočenja i vremena kočenja s praznim i napunjenim kontejnerom 


\subsection{Comparison of decelerations at different places of the container / Usporedba usporenja na različitim točkama kontejnera}

The location of the sensors S1 and S2 have been designed so that it is possible to monitor the different dynamics acting on the vehicle at the front in the lower part of the container and the rear in the upper part of the container and to compare these values with each other. This chapter of the article will, therefore, focus on the comparison of S1 and S2 and the achieved maximum decelerations with the application of filters in the form of a moving average of $80 \mathrm{~ms}, 300 \mathrm{~ms}$, and $1000 \mathrm{~ms}$ period.

When analyzing the braking courses with the application of the $80 \mathrm{~ms}$ filter, it is possible to see that in the case of an empty container, large differences in the deceleration curves are not visible. In the case of a loaded container, the difference is visible, especially in the length of the braking as in the resulting recoil after braking. The curves of S2 are shown in green colors, while the $\mathrm{S} 1$ curves are displayed in orange colors.

A comparison of the maximum acceleration values with the application of the individual filters is shown in Fig. 12.

Table 9 Comparison of maximum decelerations achieved by S1 and S2

Tablica 9. Usporedba maksimalnih usporavanja postignutih sa S1 i S2

\begin{tabular}{|c|c|c|c|c|c|c|c|c|c|c|c|c|c|}
\hline \multirow{3}{*}{ ID } & \multicolumn{6}{|c|}{ Maximum deceleration [g] } & & \multicolumn{6}{|c|}{ Maximum deceleration [g] } \\
\hline & \multicolumn{3}{|c|}{ S1 } & \multicolumn{3}{|c|}{ S2 } & & \multicolumn{3}{|c|}{ S1 } & \multicolumn{3}{|c|}{ S2 } \\
\hline & $80 \mathrm{~ms}$ & $300 \mathrm{~ms}$ & $1000 \mathrm{~ms}$ & $80 \mathrm{~ms}$ & $300 \mathrm{~ms}$ & $1000 \mathrm{~ms}$ & & $80 \mathrm{~ms}$ & $300 \mathrm{~ms}$ & $1000 \mathrm{~ms}$ & 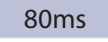 & $300 \mathrm{~ms}$ & $000 \mathrm{~ms}$ \\
\hline BT01 & -0.7114 & -0.5787 & -0.5362 & -0.7353 & -0.5844 & -0.5414 & BT09 & -0.6938 & -0.6551 & -0.5867 & -0.7631 & -0.6566 & -0.5999 \\
\hline BT02 & .7033 & -0.6483 & -0.5443 & 7068 & -0.6549 & -0.5479 & BT10 & -0.6460 & -0.5757 & -0.5465 & .7414 & 156 & 398 \\
\hline ВТ03 & -0.6824 & -0.6077 & -0.5764 & -0.7012 & -0.6129 & -0.5774 & BT11 & -0.6571 & -0.5975 & -0.5733 & -0.6589 & -0.5967 & -0.5715 \\
\hline BT04 & -0.6478 & -0.6064 & -0.5539 & -0.6593 & -0.6134 & -0.5436 & BT12 & $N / A^{*}$ & $N / A^{*}$ & $N / A^{*}$ & $N / A^{*}$ & $N / A^{*}$ & $N / A^{*}$ \\
\hline BT05 & -0.6729 & -0.6292 & -0.5245 & -0.6817 & -0.6817 & -0.5358 & BT13 & -0.6172 & -0.5452 & -0.5240 & -0.7618 & -0.5833 & -0.5387 \\
\hline BT06 & -0.7330 & -0.6905 & -0.6031 & -0.7414 & -0.6527 & -0.5811 & BT14 & -0.6413 & -0.5919 & -0.5365 & -0.7742 & -0.6188 & -0.5393 \\
\hline BT07 & -0.7217 & -0.6041 & -0.5713 & -0.6969 & -0.6093 & -0.5754 & BT15 & -0.6728 & -0.6167 & -0.5489 & -0.8498 & -0.6725 & -0.5597 \\
\hline ВТ08 & -0.7189 & -0.6930 & -0.5813 & -0.7156 & -0.6863 & -0.5755 & BT16 & -0.6407 & -0.5884 & -0.5286 & -0.7368 & -0.6168 & -0.5292 \\
\hline
\end{tabular}

Source: Authors

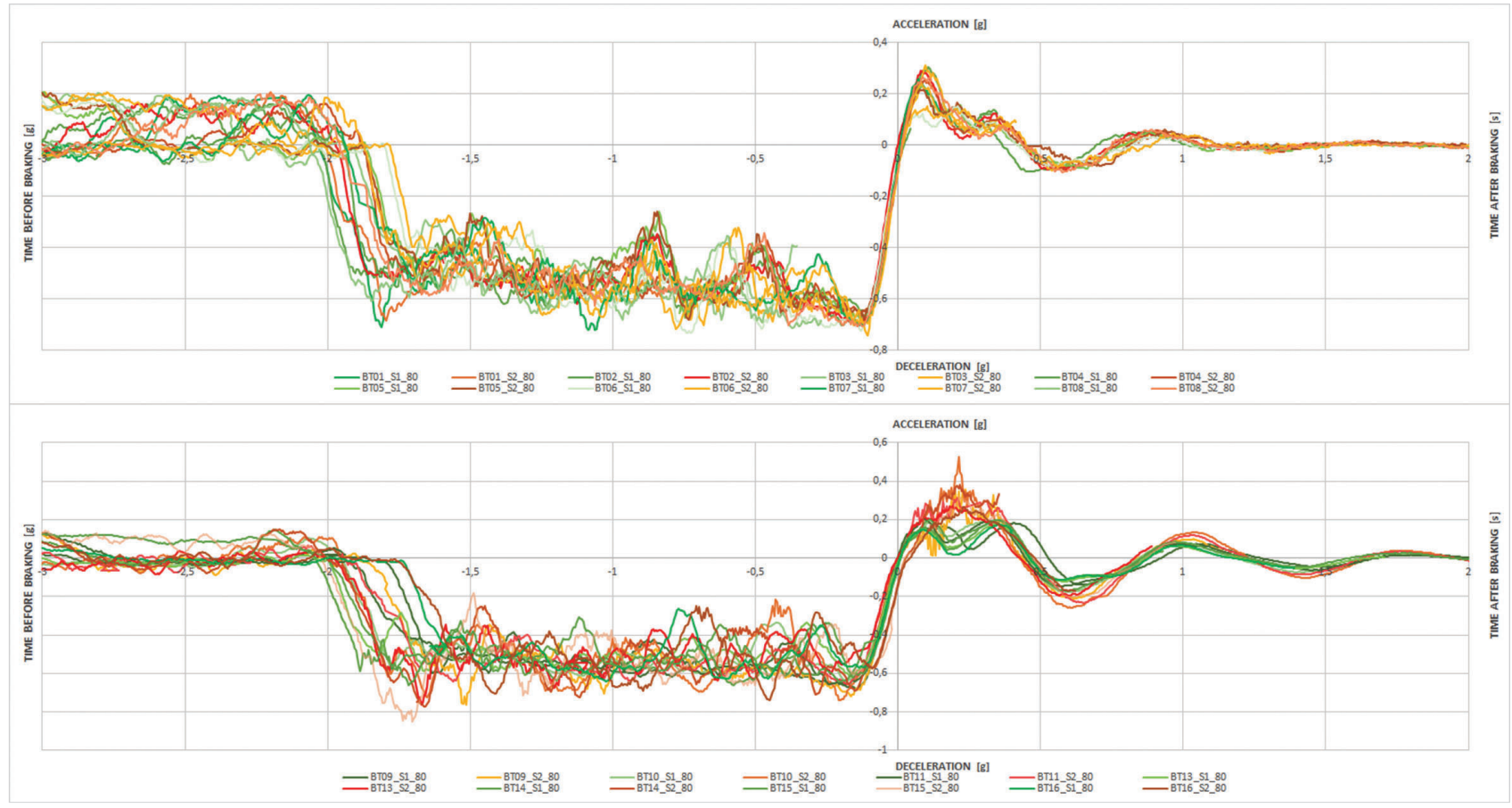

Figure 9 Comparison of S1 and S2 with 80 ms filter application Slika 9. Usporedba S1 is2 s primjenom filtra od $80 \mathrm{~ms}$

Source: Authors 


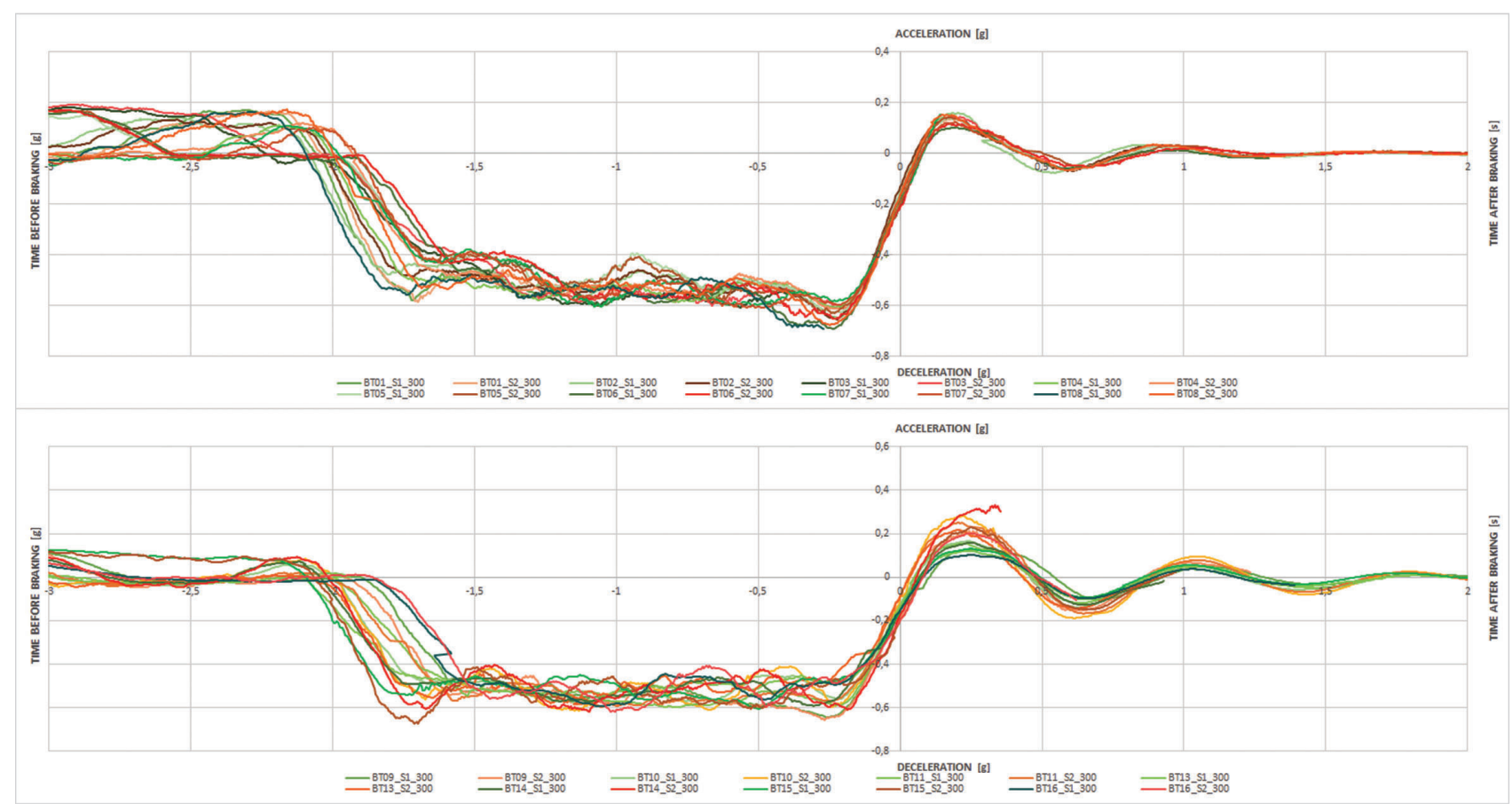

Figure 10 Comparison of S1 and S2 with 300 ms filter application.

Source: Authors Slika 10. Usporedba S1 i S2 s primjenom filtra od $300 \mathrm{~ms}$

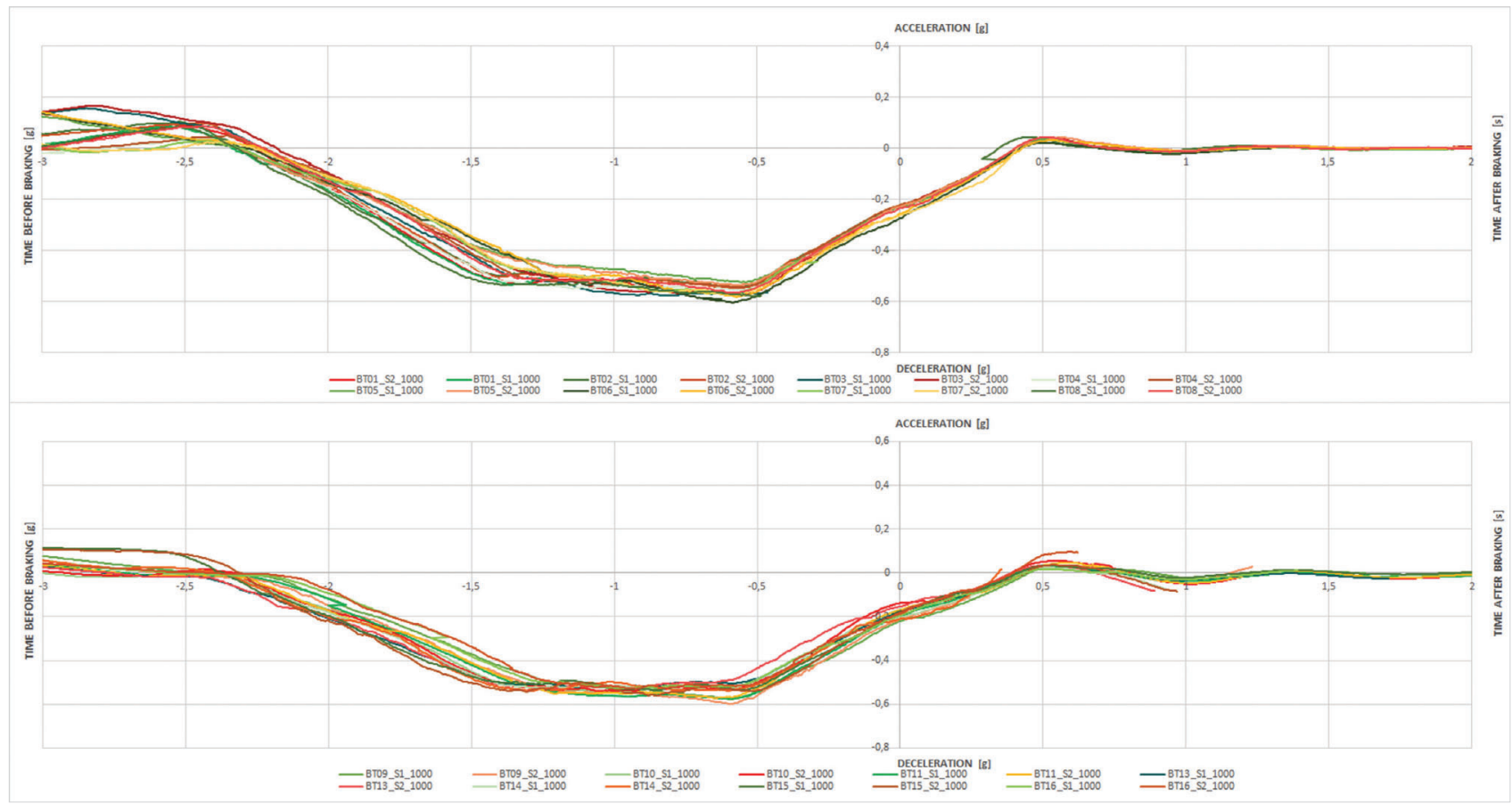

Figure 11 Comparison of S1 and S2 with 1000 ms filter application

Source: Authors Slika 11. Usporedba S1 i S2 s primjenom filtra od $1000 \mathrm{~ms}$ 


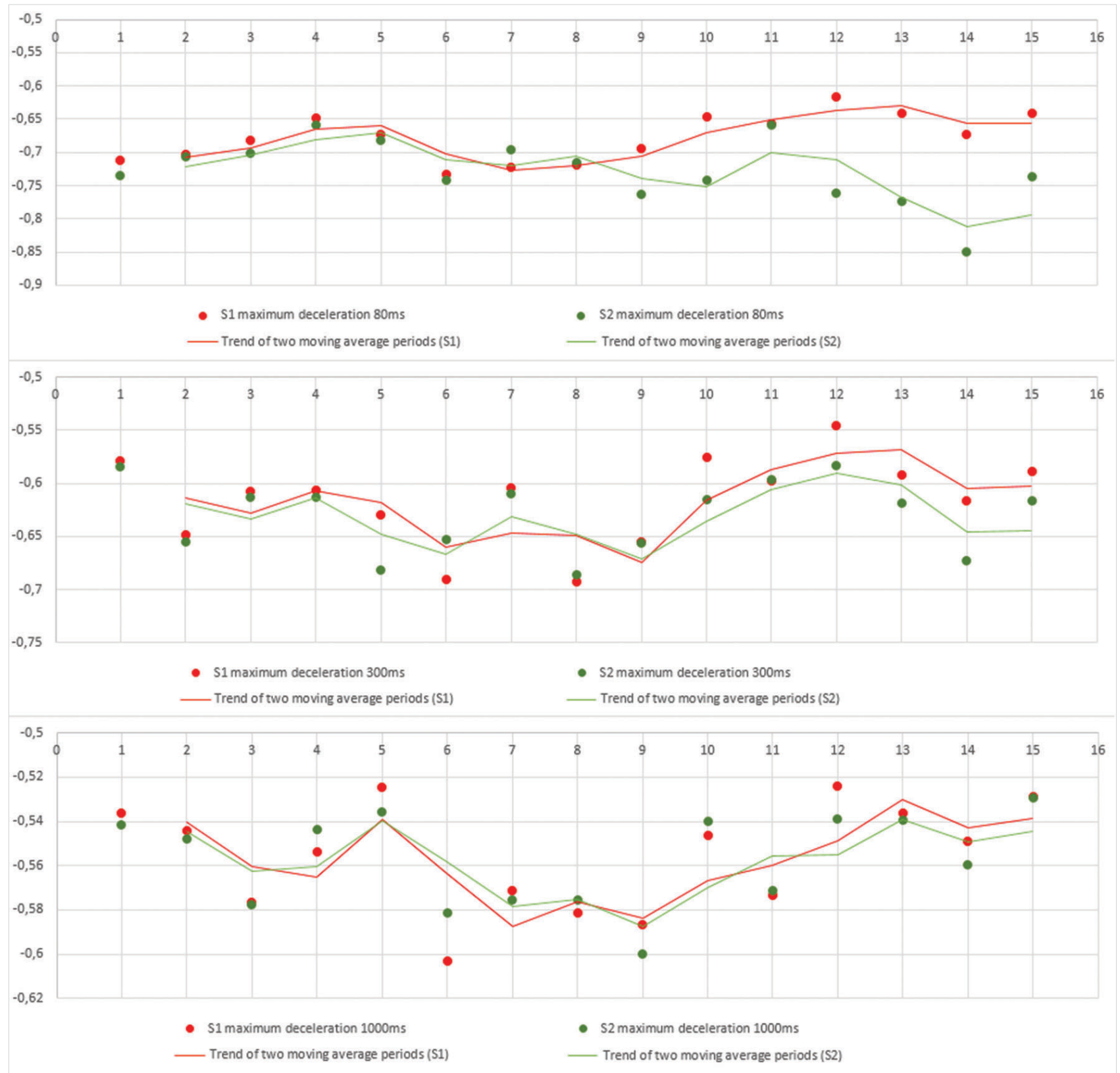

Figure 12 Comparison of measured maximum deceleration of S1 and S2 with application of filters.

Slika 12. Usporedba izmjerenog maksimalnog usporavanja S1 i S2 s primjenom filtra

Source: Authors

From Fig. 12 we can observe the differences in the maximum measured decelerations of sensors S1 and S2. The data from sensors depend on the application of a particular filter and also on whether the vehicle is empty or loaded. While the container was empty and $80 \mathrm{~ms}$ filter was applied, the maximum measured deceleration values measured by both sensors are similar, after loading the container with glass, we observe (except the measurement BT11) differences between the maximum deceleration of S1 and S2 at 0.07 to $0.18 \mathrm{~g}$. In the case of an empty container and $\mathbf{3 0 0}$ ms filter, there was a gap between the maximum deceleration measured by $\mathrm{S} 1$ and $\mathrm{S} 2$ in the fifth and sixth measurements. After loading the container, we can see comparable values from individual sensors at BT09 and BT11, other measurements show higher maximum deceleration measured by S2. When a 1000 ms filter is applied, the values measured by both sensors are comparable, the largest difference occurred in measurement BT06 with an empty container, when the maximum deceleration from the two sensors differed by approximately $0.02 \mathrm{~g}$.

It was also examined whether there was a correlation between the measured maximum decelerations. The correlation coefficient according to [39] was used:

$$
r_{x y}=\frac{\sum_{i=1}^{n}\left(x_{i}-\bar{x}\right) *\left(y_{i}-\bar{y}\right)}{\sqrt{\sum_{i=1}^{n}\left(x_{i}-\bar{x}\right)^{2} *\left(y_{i}-\bar{y}\right)^{2}}}
$$

The correlation coefficient gives a statistical linear relationship between the values of the variables $X$ and $Y$. The correlation between individual sensors and filters was determined separately for braking with an empty container, separately for a loaded container and subsequently between decelerations achieved by one sensor, where we compared the correlation between BT01-BT08 to BT09-BT16. 
Table 10 Correlation coefficients

Tablica 10. Koeficijenti korelacije

\begin{tabular}{|c|c|c|c|c|c|c|c|c|c|c|c|}
\hline \multirow{10}{*}{$\sum_{i=}^{\grave{L}}$} & & r value & corr. & \multirow{10}{*}{$\begin{array}{l}\text { 岃 } \\
\text { oิ }\end{array}$} & & rvalue & corr. & \multirow{10}{*}{ 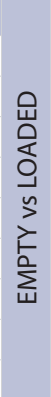 } & & rvalue & corr. \\
\hline & $\mathrm{S} 1 \mathrm{~S} 2 \_80 \mathrm{~ms}$ & 0.8579 & SDD & & $\mathrm{S} 1 \mathrm{~S} 2 \_80 \mathrm{~ms}$ & 0.1976 & WDD & & S1ES1L_80ms & 0.3602 & WDD \\
\hline & S1S3_80ms & 0.5917 & MDD & & S1S3_80ms & 0.8400 & SDD & & S2ES2L_80ms & 0.0221 & $\mathrm{LI}$ \\
\hline & S2S3_80ms & 0.2975 & WDD & & S2S3_80ms & -0.0556 & LI & & S3ES3L_80ms & -0.2352 & WID \\
\hline & $\mathrm{S} 1 \mathrm{~S} 2 \_300 \mathrm{~ms}$ & 0.8130 & SDD & & $\mathrm{S} 1 \mathrm{~S} 2 \_300 \mathrm{~ms}$ & 0.8061 & SDD & & S1ES1L_300ms & -0.5182 & MID \\
\hline & S1S3_300ms & 0.9438 & SDD & & S1S3_300ms & 0.9244 & SDD & & S2ES2L_300ms & -0.6517 & MID \\
\hline & $\mathrm{S} 2 \mathrm{~S} 3 \_300 \mathrm{~ms}$ & 0.9012 & SDD & & S2S3_300ms & 0.6296 & MDD & & S3ES3L_300ms & -0.3816 & WID \\
\hline & S1S2_1000ms & 0.9370 & SDD & & $\mathrm{S} 1 \mathrm{~S} 2$ _1000ms & 0.9444 & SDD & & S1ES1L_1000ms & -0.1409 & WID \\
\hline & S1S3_1000ms & 0.9230 & SDD & & S1S3_1000ms & 0.9784 & SDD & & S2ES2L_1000ms & -0.2114 & WID \\
\hline & S2S3_1000ms & 0.9550 & SDD & & S2S3_1000ms & 0.9315 & SDD & & S3ES3L_1000ms & -0.0533 & $\mathrm{LI}$ \\
\hline
\end{tabular}

Source: Authors

If the correlation coefficient reaches a value from -1 to -0.7 or +1 to +0.7 , we speak of strong indirect/direct dependence (SID/SDD). If the correlation coefficient reaches a value from -0.7 to -0.4 or +0.7 to +0.4 , it is a middle indirect/direct dependence (MID/MDD). If the correlation coefficient is at the level from -0.4 to -0.1 or +0.4 to +0.1 , it is a weak indirect/direct dependence (WID/WDD). A correlation coefficient in the range -0.1 to +0.1 indicates linear independence.

When looking at the correlation coefficients from the maximum deceleration in the case of an empty container, it is always a strong direct dependence (SDD), except for the cases S1S3 and S2S3 with the application of the $80 \mathrm{~ms}$ filter. In the

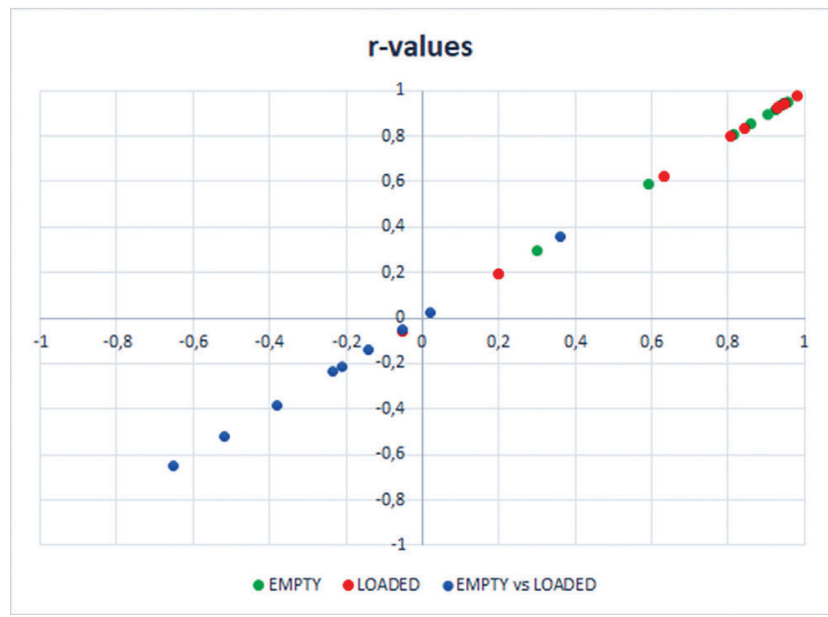

Figure 13 Correlation coefficients (r-values) Source: Authors case of a loaded container, in most cases it is also a strong direct dependence (SDD), except for the cases S1S2 and S2S3 with a S2S3 with a 300 ms filter, which is MDD. In the case of the correlation coefficients, where the empty and loaded containers were compared, it is mainly a weak and middle indirect dependence.

\subsection{Axle load changes / Promjene osovinskog opterećenja}

Before the measurements, the load of the axles of the vehicle was determined. These weights were also measured after the first series of measurements, i.e. after tests with an empty container, after four braking tests with a loaded container, after a short driving test and after all measurements had been completed. The weighbridge was used to determine the front axle load, the total weight of the vehicle, and the load of the rear tandem axle. These values are processed in the following table and graph.

Primary load changes on the front axle and rear tandem axle were monitored after tests. Due to braking tests, the bulk cargo was naturally pushed forward in the container, which was reflected in the change of load on the front axle - after four braking tests with cargo, the load on the front axle increased by $280 \mathrm{~kg}(+3.6 \%)$. Since the subsequent driving test was performed with ascent and descent and multiple intensive braking, the load has leveled. After all tests, it was found that the load on the front axle increased by $400 \mathrm{~kg}(+5.18 \%)$, while the load on the rear tandem axle decreased by $360 \mathrm{~kg}(-2.23 \%)$. The inaccuracy and deviations arising from the measurements and the weighbridge shall also be taken into account.

Table 11 Weights after measurements

Tablica 11. Težine nakon mjerenja

\begin{tabular}{|c|c|c|c|c|c|c|c|c|c|c|c|}
\hline Cargo & Container & Measured & $\begin{array}{c}\text { Front } \\
\text { axle [kg] }\end{array}$ & Diff $[\mathrm{kg}]$ & Diff [\%] & $\begin{array}{c}\text { Total weight } \\
{[\mathrm{kg}]}\end{array}$ & $\begin{array}{l}\text { Diff } \\
{[\mathrm{kg}]}\end{array}$ & $\begin{array}{l}\text { Diff } \\
{[\%]}\end{array}$ & $\begin{array}{l}\text { Rear tandem } \\
\text { axle [kg] }\end{array}$ & Diff $[\mathrm{kg}]$ & $\begin{array}{l}\text { Diff } \\
{[\%]}\end{array}$ \\
\hline Without & Without & Before tests & 6200 & - & - & 12620 & - & - & 6350 & - & - \\
\hline Without & \multirow{5}{*}{ KAB25 } & Before tests & 6510 & +310 & +5 & 14970 & +2350 & +18.6 & 8450 & +2100 & +33.1 \\
\hline \multirow{4}{*}{$\begin{array}{l}\text { Waste } \\
\text { glass }\end{array}$} & & Before tests & 7720 & +1210 & +18.6 & 23980 & +9010 & +60.2 & 16160 & +7710 & +91.2 \\
\hline & & After 4 braking tests & 8000 & +280 & +3.6 & 23980 & - & - & 15850 & -310 & -1.9 \\
\hline & & After driving test & 8040 & +40 & +0.5 & 23980 & - & - & 15940 & +90 & +0.6 \\
\hline & & After 8 braking tests & 8120 & +80 & +1 & 23980 & - & - & 15800 & -140 & -0.9 \\
\hline
\end{tabular}

Source: Authors 


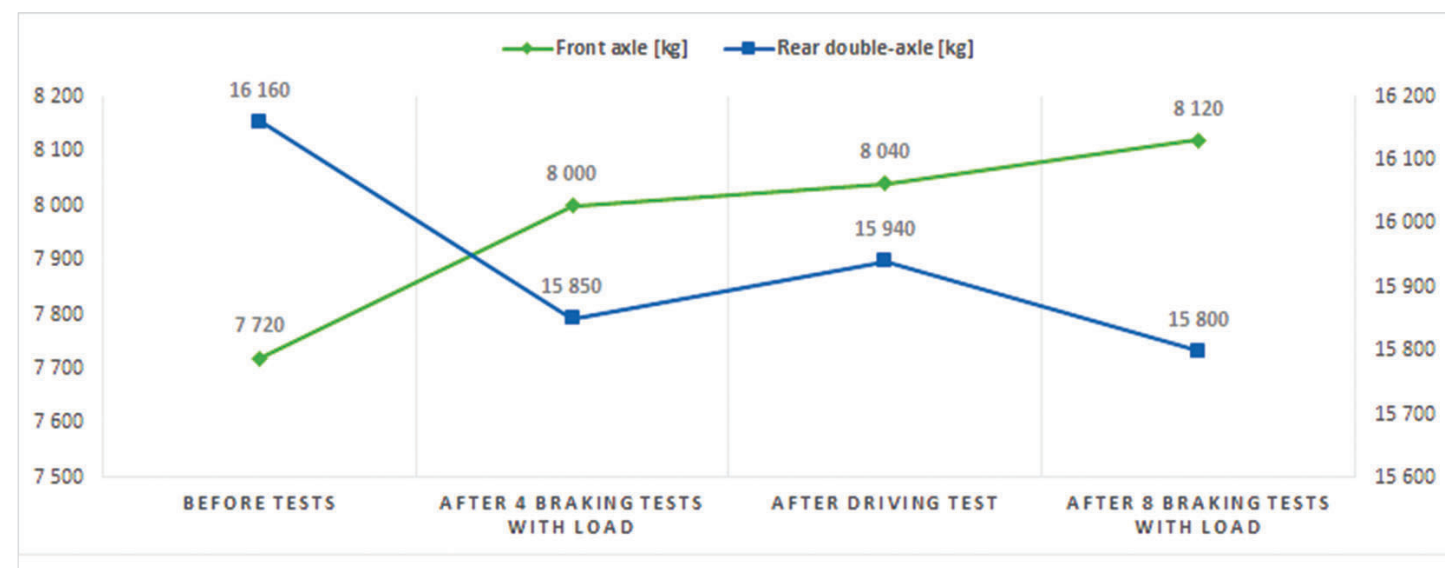

Figure 14 Change in front axle and rear tandem axle load

Source: Authors

Slika 14. Promjena opterećenja prednje i stražnje tandemske osovine

\section{CONCLUSION / Zaključak}

In this article, we dealt with the evaluation of the dynamics of bulk cargo in the intermodal container ACTS. We performed several measurements to identify the acceleration that affects the bulk cargo in the container we chose. The measurements were performed with the empty container, then with the loaded container. To measure acceleration, we used two sensors located in different parts of the container, and two cameras to record the movement of the vehicle and the movement of the cargo in the container. The measured acceleration values due to the nature of the sensors used cannot be evaluated directly, so it was necessary to make adjustments by applying a suitable filter.

Due to the requirements of the prEN 17321:2020 standard, we used a moving average of $80 \mathrm{~ms}, 300 \mathrm{~ms}$, and $1000 \mathrm{~ms}$. We evaluated the filtered data with the help of software in tabular and graphical form. From the results we can see that the braking distance, braking time, and MFDD of the vehicle with empty and loaded container do not change significantly, while taking into account the fact that the initial speed of the vehicle before braking differs slightly in both empty and loaded container tests. However, the difference is noticeable in the curves of braking, when the vehicle is stopped, and when the recoil occurs. Its duration is shorter when the container is empty than the case when the container is loaded. This deviation is most visible with the 80 ms filter. This phenomenon can be caused by a change in the height of the vehicle's center of gravity due to the bulk cargo, which also affects the change in the front and read tandem axle load during braking and thus the vehicle's suspensions tend to return. The difference is also observed at the maximum deceleration values achieved by S1 and S2 when the container was loaded. This difference is again most pronounced with the 80 ms filter application, with the $300 \mathrm{~ms}$ and 1000 ms filters are comparable.

We assume that during braking there was a suspension of the front axle and subsequent impact on the suspension stops, which significantly affected the angular speed of tilting the vehicle forward. S2 was placed at a higher height, where changes in the angular speed of the vehicle are more pronounced during braking. After tests, the front axle load increased by $400 \mathrm{~kg}$, which exceeded its technical permissible maximum weight by $120 \mathrm{~kg}$. The loading organization should also take into account the fact that the dynamic changes with bulk cargo may occur when the vehicle is in operation and these shipments should be modeled in such a way that the maximum axle weights are not exceeded.

\section{REFERENCES / Literatura}

[1] Wiśnicki B., Dyrda A.: Analysis of the intermodal transport efficiency in the central and eastern Europe. In: Naše more (ISSN 0469-6255), Volume 63, Issue 2, May 2016, pp. 43-47. https://doi.org/10.17818/nm/2016/2.1

[2] Gnap J., Kubanova J.: Selected options for modelling of transport processes particularly in relation to intermodal transport. In 18th International Scientific Conference, LOGI 2017; Clarion Congress Hotel Ceske Budejovice; Czech Republic; 19 October 2017, pp. 144-150. (ISBN: 978-1-5108-5191-7), DOI: $10.1051 /$ matecconf/201713400021. https://doi.org/10.1051/mate cconf/201713400015

[3] Gnap J., Poliak M., Semanova S.: The issue of a transport mode choice from the perspective of enterprise logistics. In Open Engineering, (E-ISSN 2391-5439), 2019. Volume 9, Issue 1, pp. 374-383. https://doi.org/10.1515/eng-2019-0044

[4] Gnap J., Kalasova A., Gogola M., Ondrus J.:The Cente of Excellence for transport service and control. In Communications - Scientific Letters of the University of Zilina. (ISSN 1335-4205), Volume 12, Issue 3A, 2010, pp. 116-120.

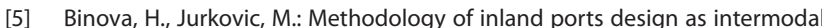
terminals in the Czech Republic. In: Carpathian Logistics Congress (CLC 2015) - Conference procedings, p. 126-131, Jesenik, Czech Republic. November 04-06, 2015. Published: 2016. ISBN 978-80-87294-64-2.

[6] Galierikova A., Sosedova J.: Intermodal transportation of dangerous goods. In: Naše more (ISSN 0469-6255), Volume 65, Issue 3, September 2018, pp. 8-11. https://doi.org/10.17818/nm/2018/3.8

[7] Jagelcak J., Zamecnik J., Kiktova M.: Potential for intermodal transport of chemical goods in Slovakia. In 18th International Scientific Conference, LOGI 2017; Clarion Congress Hotel Ceske Budejovice; Czech Republic; 19 October 2017, pp. 144-150. (ISBN: 978-1-5108-5191-7), https://doi.org/10.1051/ matecconf/201713400021

[8] Jagelcak J., Kiktova M., Stopkova M.: The application of the verified gross mass of intermodal loading units in the conditions of the Slovak Republic. In: Naše more (ISSN 0469-6255), Volume 65, Issue 4 Special Issue, October 2018, pp. 218-223. https://doi.org/10.17818/nm/2018/4si.10

[9] Theophilus C, N., Eba, M., Ifiok, O. \& Leonard, N. (2018). Assessment of Shippers and Ship Owners Ship and Charter Type Choice in the Wet and Dry Bulk Ship Brokering Market: Knowledge Guide for African Indigenous Ship Brokers. LOGI - Scientific Journal on Transport and Logistics, 9(1), 70-82. https://doi.org/10.2478/logi-2018-0009

[10] Ližbetin J., Vejs P., Stopka O., Cempírek V.:The significance of dynamic detection of the railway vehicles weight. In: Naše more (ISSN 0469-6255), Volume 63, Issue 3, July 2016, pp. 156-160. https://doi.org/10.17818/nm/2016/si15

[11] Bańka, M.,Droździel, P., \& Nieoczym, A. (2019). Lashing methods-mathematical basis of the process of selecting the number of lashings. In: 23rd International Scientific Conference on Transport Means 2019, Hotel Gabija Palanga, Lithuania, 2-4 October 2019, Code 152673. ISSN 1822-296X.

[12] Bupić M., Pavković B., Jemrić T.: Simulation model of dynamic behaviour of refrigerated products in a ship's refrigerated container. In: Naše more (ISSN 0469-6255), Volume 57, Issue 5-6, December 2010, pp. 226-234.

[13] Náhlík T., Smetanová D.: Applications of gyroscopic effect in transportation. In: Naše more (ISSN 0469-6255), Volume 65, Issue 4 Special Issue, October 2018, pp. 293-296. https://doi.org/10.17818/nm/2018/4si.24

[14] Vlkovsky M, Vlachova H.: Securing cargo during transport on roads of different quality. In VEHITS 2019 - Proceedings of the 5th International Conference on Vehicle Technology and Intelligent Transport 2019, Heraklion, Crete, 3 May to 5 May 2019, pp. 25-32. https://doi.org/10.5220/0007617900250032 
[15] Gnap J., Skrucany T., Sarkan B.: Influence of aerodynamic trailer devices on drag reduction measured in a wind tunnel. In Exksploatacja i Niezawodnosc, (ISSN: 1507-2711), Volume 18, Issue 1, 2016, pp. 151-154. https://doi. org/10.17531/ein.2016.1.20

[16] Marienka P., Francak M., Kiktova M, Jagelcak J.: Video recordings for the evaluation of braking tests with load. In 13th International Scientific Conference on Sustainable, Modern and Safe Transport, TRANSCOM 2019: Novy Smokovec, Slovakia, 29 May 2019 to 31 May 2019, in Transportation Research Procedia (ISSN 2352-1457), Volume 40, pp. 354-361. https://doi. org/10.1016/j.trpro.2019.07.052

[17] Skrucany T., Synak F., Semanova S., Ondrus J., Rievaj V.: Detection of road vehicle's centre of gravity. In 11th International Science and Technical Conference AUTOMOTIVE SAFETY 2018, Casta Papiernicka, Slovakia, 18 April 2018 to 20 April 2018. pp. 1-7. https://doi.org/10.1109/ autosafe.2018.8373334

[18] Vrabel J., Jagelcak J., Zamecnik J., Caban J.: Influence of Emergency Braking on Changes of the Axle Load of Vehicles Transporting Solid Bulk Substrates. In 10th International Scientific Conference TRANSBALTICA 2017, Vilnius, Lithuania, 4 May 2017 to 5 May 2017, Volume 187 pp. 89-99. https://doi. org/10.1016/j.proeng.2017.04.354

[19] Rybicka, I., Caban, J., Vrabel, J., Sarkan, B., Stopka, O., Misztal, W.: Analysis of the safety systems damage on the example of a suburban transport enterprise. In 11th International Science and Technical Conference AUTOMOTIVE SAFETY 2018, Casta Papiernicka, Slovakia, 18 April 2018 to 20 April 2018. https://doi.org/10.1109/autosafe.2018.8373323

[20] Ondrus J., Vrabel J., Kolla E.: The influence of the vehicle weight on the selected vehicle braking characteristics. In 22nd International Scientific Conference Transport Means 2018, Trakai, Lithuania, 3 October 2018 to 5 October 2018. Volume 2018, pp. 384-390.

[21] Gnap J., Skrucany T.: The effect of the crosswinds on the stability of the moving vehicles. In Applied Mechanics and Materials: 6th International Scientific Conference on Dynamic of Civil Engineering and Transport Structures and Wind Engineering, DYN-WIN 2014, Donovaly, Slovakia, May 25 to 29 2014. (ISSN 1660-9336), Volume 617, pp. 296-301. https://doi. org/10.4028/www.scientific.net/amm.617.296

[22] RievajV.,VrabelJ., SynakF.:The Effects of vehicle load on driving characteristics. In Advances in science and technology research journal, Volume 12, Issue 1, pp. 142-149. 2018. https://doi.org/10.12913/22998624/80896

[23] Vlkovsky M., Ivanusa T., Neumann V., Foltin P., Vlachova H.: Optimizating cargo security during transport using dataloggers. In Journal of Transportation Security, (ISSN 1938-7741), Volume 10, Issue 3-4, 2017. pp. 63-71. https://doi. org/10.1007/s12198-017-0179-4

[24] Ondrus, J., Kolla, E.:Practical use of the braking attributes measurements results. In: MATEC web of conferences: LOGI 2017 - 18th international scientific conference: České Budějovice, Czech Republic, October 19, 2017. (ISSN 2261-236X). Vol. 134, art. no. 00044 (2017). https://doi.org/10.1051/matecconf/201713400044

[25] Skrucany, T., Vrabel J., Kazimir, P.: The influence of the cargo weight and its position on the braking characteristics of light commercial vehicles. In Open Engineering, (E-ISSN 2391-5439) 2020, Vol. 10, Issue 1, pp. 154-165, (E-ISSN 2391-5439). https://doi.org/10.1515/eng-2020-0024

[26] Tarkowski S., Nieoczym A., Caban J., Gardynski L., Vrabel J.: Reconstruction of road accident using video recording. In 3rd International conference of computational methods in engineering science CMES 18, Kazimierz Dolny, Poland, November 22 to 242018 Volume 252, Article 05023, https://doi. org/10.1051/matecconf/201925205023
[27] Vlkovsky M., Binar T., Svarc J., Nemec P., Bucsuhazy K.: Impact of shocks on cargo securing during the road transport. In IOP Conference Series: Materials Science and Engineering: 4th World Multidisciplinary Civil EngineeringArchitecture-Urban Planning Symposium WMCAUS 2019, Prague, Czech Republic 17 June to 21 June 2019. (ISSN 1757-8981), Volume 603, Issue 3 , Article number 032045. https://doi.org/10.1088/1757-899x/603/3/032045

[28] Skrucany T., Vrabel J., Kendra M.: Impact of Cargo Distribution on the Vehicle Flatback on Braking Distance in Road Freight Transport. In 18th International Scientific Conference, LOGI 2017; Clarion Congress Hotel Ceske Budejovice; Czech Republic; 19 October 2017, pp. 144-150. (ISBN: 978-1-5108-51917), DOI: 10.1051/matecconf/201713400021, https://doi.org/10.1051/ matecconf/201713400054

[29] Ondrus, J., Kolla, E.: The impact of ABS system on the braking characteristics of the specified motorcycle on the dry road surface. In: International Automotive Conference (KONMOT 2018). (ISSN 1757-8981). 1. vyd. [S.I.]: IOP Publishing, 2018. pp. 1-10. https://doi.org/10.1088/1757-899x/421/2/022024

[30] Rievaj V., Sulgan M., Hudak A., Jagelcak J.: The car and its dynamics. EDIS University of Zilina. 2013. ISBN 978-80-554-0627-5.

[31] Liščák, Š.: Reliability in road vehicle operation, 1. Issue., Žilina : University of Žilina, 2002, 192s., ISBN 80-7100-969-5.

[32] Regulation No 13 of the Economic Commission for Europe of the United Nations (UN/ECE) - Uniform provisions concerning the approval of vehicles of categories M, N and O with regard to braking [2016/194]

[33] Decree of Ministry of Transport and Construction of the Slovak Republic no. 137/2018 Coll., which lays down details on technical inspections.

[34] Decree of Ministry of Transport and Construction of the Slovak Republic no. 134/2018 Coll., which lays down details on the operation of vehicles in road traffic.

[35] Methodical instruction of the Ministry of Transport and Construction of the Slovak Republic no. 74/2018 for performing inspections of brake systems of vehicles of categories $\mathrm{M} 1$ with the maximum permissible weight over 3,5t, $\mathrm{M} 2, \mathrm{M} 3, \mathrm{~N} 2, \mathrm{~N} 3, \mathrm{O} 3$ and $\mathrm{O} 4$ on cylindrical brake test benches.

[36] Methodical instruction of the Ministry of Transport and Construction of the Slovak Republic no. $48 / 2018$, which lays down control items related to the braking device.

[37] prEN 17321:2020. Intermodal loading units and commercial vehicles. Transport stability of packages. Minimum requirements and tests.

[38] EN 12195-1:2010. Load restraining on road vehicles. Safety. Calculation of securing forces. https://doi.org/10.3403/30213241

[39] Konečný V., Poliak M., Poliaková A.: Ekonomická analýza podniku cestnej dopravy. EDIS - University of Zilina. 2010. ISBN 978-80-554-0253-6.

[40] Stopka, O., Kampf, R. Determining the most suitable layout of space for the loading units' handling in the maritime port. Transport 33(1), 2018, pp. 280 290. https://doi.org/10.3846/16484142.2016.1174882

[41] Kudlac, S., Gasparik, J., Dedik, M. \& Kurenkov, P. V. (2018). Identification of Restricting Criteria for Comprehensive Assessment of Logistics Chains in Intermodal Transport. LOGI - Scientific Journal on Transport and Logistics, 9(2), 18-27. https://doi.org/10.2478/logi-2018-0015

[42] Ližbetin, J., Stopka, O. (2020). Application of Specific Mathematical Methods in the Context of Revitalization of Defunct Intermodal Transport Terminal: A Case Study. Sustainability, 12(6), Art. no. 2295.https://doi.org/10.3390/ su12062295 